\title{
Mitochondrial phylogenomics of the Bivalvia (Mollusca): searching for the origin and mitogenomic correlates of doubly uniparental inheritance of $\mathrm{mtDNA}$
}

Hélène Doucet-Beaupré ${ }^{1,2^{*}}$, Sophie Breton ${ }^{2}$, Eric G Chapman ${ }^{3}$, Pierre U Blier ${ }^{1}$, Arthur E Bogann ${ }^{4}$, Donald T Stewart ${ }^{5}$, Walter R Hoeh ${ }^{2}$

\begin{abstract}
Background: Doubly uniparental inheritance (DUI) is an atypical system of animal mtDNA inheritance found only in some bivalves. Under DUI, maternally (F genome) and paternally ( $M$ genome) transmitted mtDNAs yield two distinct gender-associated mtDNA lineages. The oldest distinct $M$ and $F$ genomes are found in freshwater mussels (order Unionoida). Comparative analyses of unionoid mitochondrial genomes and a robust phylogenetic framework are necessary to elucidate the origin, function and molecular evolutionary consequences of DUI. Herein, $\mathrm{F}$ and $\mathrm{M}$ genomes from three unionoid species, Venustaconcha ellipsiformis, Pyganodon grandis and Quadrula quadrula have been sequenced. Comparative genomic analyses were carried out on these six genomes along with two $\mathrm{F}$ and one $\mathrm{M}$ unionoid genomes from GenBank ( $\mathrm{F}$ and $\mathrm{M}$ genomes of Inversidens japanensis and $\mathrm{F}$ genome of Lampsilis ornata).
\end{abstract}

Results: Compared to their unionoid F counterparts, the M genomes contain some unique features including a novel localization of the trnH gene, an inversion of the atp8-trnD genes and a unique $3^{\prime}$ coding extension of the cytochrome c oxidase subunit II gene. One or more of these unique $\mathrm{M}$ genome features could be causally associated with paternal transmission. Unionoid bivalves are characterized by extreme intraspecific sequence divergences between gender-associated mtDNAs with an average of 50\% for V. ellipsiformis, 50\% for I. japanensis, $51 \%$ for P. grandis and 52\% for Q. quadrula (uncorrected amino acid p-distances). Phylogenetic analyses of 12 protein-coding genes from 29 bivalve and five outgroup mt genomes robustly indicate bivalve monophyly and the following branching order within the autolamellibranch bivalves: ((Pteriomorphia, Veneroida) Unionoida).

Conclusion: The basal nature of the Unionoida within the autolamellibranch bivalves and the previously hypothesized single origin of DUI suggest that (1) DUI arose in the ancestral autolamellibranch bivalve lineage and was subsequently lost in multiple descendant lineages and (2) the mitochondrial genome characteristics observed in unionoid bivalves could more closely resemble the DUI ancestral condition. Descriptions and comparisons presented in this paper are fundamental to a more complete understanding regarding the origins and consequences of DUI.

\footnotetext{
* Correspondence: helene.dbeaupre@cgocable.ca

'Département de Biologie, Université du Québec à Rimouski, 300 Allée des Ursulines, Rimouski, Québec, G5L 3A1, Canada
} 


\section{Background}

Mitochondrial DNA (mtDNA) is the only extranuclear genome in animal cytoplasm. Located in the matrix of mitochondria, metazoan mtDNA is normally a small circular DNA molecule about 14-16 kilobases (kb) long usually encoding the same 37 genes $([1,2]$; but see [3] for exceptions). Typically, all mtDNAs in the zygote come from the oocyte and even though evidence for occasional paternal leakage has been reported [4,5], animal mtDNA is thought to strictly follow maternal inheritance [6]. This clonal inheritance coupled with the successive cell divisions that represent sequential bottlenecks for the mitochondrial population [6-8] result in an essentially homoplasmic state for mtDNA. An extreme exception to the paradigm of strict maternal inheritance of animal mtDNA (SMI) is found in three bivalve lineages (i.e., the orders Mytiloida, Unionoida and Veneroida), which possess an unusual system termed doubly uniparental inheritance of mtDNA (DUI) (see $[9,10]$ for reviews).

In DUI-possessing organisms, distinct gender-associated mitochondrial DNA lineages coexist: a female-transmitted (F) genome and a male-transmitted (M) genome. Under DUI, female bivalves transmit their mitochondria (carrying F mtDNA) to both sons and daughters, as in SMI, but males pass on their mitochondria (via sperm carrying $M$ mtDNA) to only sons (e.g., [11] but see [12]). At the organismal level, male bivalves with DUI are thus heteroplasmic and contain both $\mathrm{M}$ and $\mathrm{F}$ genomes. In male somatic tissues, the $\mathrm{F}$ genome predominates while in male gonadal tissues, the $\mathrm{M}$ genome is predominant [13] and it appears to be the exclusive type in sperm [14]. In females, both somatic and gonadal tissues typically contain the F genome, but the occasional presence of a small amount of the $M$ genome has been demonstrated in somatic tissues and ovaries of some species [12-16].

The broad taxonomic distribution of DUI within the Bivalvia (e.g., [17-26]) reinforces the idea that it evolved once in an ancestral bivalve lineage, from standard uniparental inheritance, and was lost in some descendant bivalve lineages (e.g., oysters and probably scallops) $[23,27,28]$. DUI could then be the ancestral condition for the Bivalvia, however, a more definitive statement to this effect rests on producing a more reliable bivalve phylogeny along with clarifying the distribution of DUI in additional bivalve lineages. Although many of the essential elements of DUI have been described, (i.e., distinct $\mathrm{M}$ and $\mathrm{F}$ lineages, heteroplasmy in males, rapid molecular evolution particularly of $M$ types [17-19,21,22,24,29-31], the current and/or historical function of DUI still remains a mystery. Comparisons of entire $\mathrm{F}$ and $\mathrm{M}$ genomes (as opposed to partial sequences of a few genes) will enable the characterization of potential gene content/organizational/functional differences between the $\mathrm{M}$ and $\mathrm{F}$ genomes, and will help to reconstruct the history of any possible recombination and/or gene translocation events in these distinct, gender-associated lineages.

To date, 15 complete or nearly complete $F$ and $M$ mtDNA genome sequences are available for species with DUI but these are numerically biased towards marine taxa (i.e., species from the Mytiloida and Veneroida) [32-37] (Table 1). While the vertebrate mitochondrial gene order is almost invariant, mollusks, and bivalves in particular, exhibit radical rearrangements of mitochondrial genes and extensive mtDNA variability at the intrageneric level $[2,38,39]$. For example, the two congeneric oyster species Crassostrea virginica and C. gigas, both lacking DUI [28], show broad differences in gene content and gene order with relocation of most tRNA genes $[2,40]$. At the species level, the extent of genome rearrangement between the two distinct gender-associated mitochondrial genomes appears to vary greatly among the three divergent bivalve lineages. In the Mytiloida, the gene order and content of $\mathrm{F}$ and $\mathrm{M}$ genomes from a species are conserved but both lack the gene for ATPase subunit 8 (atp 8$)$ and have a second tRNA gene for methionine (trnM) $[31,34,36]$. By contrast, in the marine clam Venerupis philippinarum, gene content differs between $\mathrm{M}$ and $\mathrm{F}$ genomes as we observe a gene duplication for the cytochrome $c$ oxidase subunit II gene (cox2) in the $\mathrm{F}$ genome and an extra $\operatorname{trn} M$ in the $\mathrm{M}$ genome, and both genomes have a short atp 8 gene (37 amino acids) the function of which is unclear $[2,41]$. In freshwater mussels, an $M$ genome-specific 3' extension of the cytochrome $c$ oxidase subunit II gene (Mcox2) has been clearly demonstrated $[22,25,42]$. This functional extension is a unique feature of unionoid $\mathrm{M}$ genomes and typically yields an $\sim 80 \%$ increase in gene length relative to the female-transmitted $\operatorname{cox} 2$ gene [43]. In unionoid bivalves, the presence of atp 8 has been confirmed in both $\mathrm{M}$ and $\mathrm{F}$ genomes [2,37]. Also, the F genomes of Inversidens japanensis and Hyriopsis cumingii (both in the subfamily Gonideinae) exhibit a different gene order compared with the M genome of I. japanensis and the F genome of Lampsilis ornata ([37]; Zheng $\mathrm{RL}$ and Li JL, personal communication) (see Table 1). Analysis of gene order for additional $\mathrm{F}$ and $\mathrm{M}$ mtDNA genomes from freshwater mussels will allow us to test the following alternative hypotheses: (1) the translocation of several genes as observed in the F genomes of $I$. japanensis and $H$. cumingii represents an idiosyncratic gene rearrangement unique to these species or to the subfamily Gonideinae or (2) that this gene arrangement is in fact a characteristic shared with other unionoid species' F genomes or other subfamily. 
Table 1 Species and GenBank accession numbers of the sequences used in this study for phylogenetic analyses.

\begin{tabular}{|c|c|c|}
\hline Species & Gender & $\begin{array}{l}\text { GenBank accession } \\
\text { Numbers }\end{array}$ \\
\hline \multicolumn{3}{|l|}{ Bivalvia } \\
\hline \multicolumn{3}{|l|}{ Autolamellibranchiata } \\
\hline \multicolumn{3}{|l|}{ Unionoida } \\
\hline $\begin{array}{l}\text { Venustaconcha } \\
\text { ellipsiformis }\end{array}$ & $\mathrm{F}$ & FJ809753 \\
\hline $\begin{array}{l}\text { Venustaconcha } \\
\text { ellipsiformis }\end{array}$ & M & FJ809752 \\
\hline Pyganodon grandis & $\mathrm{F}$ & FJ809754 \\
\hline Pyganodon grandis & M & FJ809755 \\
\hline Inversidens japanensis & $\mathrm{F}$ & AB055625 \\
\hline Inversidens japanensis & M & AB055624 \\
\hline Quadrula quadrula & $\mathrm{F}$ & FJ809750 \\
\hline Quadrula quadrula & M & FJ809751 \\
\hline Lampsilis ornata & $\mathrm{F}$ & NC_005335 \\
\hline Hyriopsis cumingii & $\mathrm{F}$ & NC_011763 \\
\hline \multicolumn{3}{|l|}{ Veneroida } \\
\hline Venerupis philippinarum & $\mathrm{F}$ & NC_003354 \\
\hline Venerupis philippinarum & M & AB065374 \\
\hline $\begin{array}{l}\text { Acanthocardia } \\
\text { tuberculata }\end{array}$ & - & NC_008452 \\
\hline Sinonovacula constricta & - & NC_011075 \\
\hline Hiatella arctica & - & NC_008451 \\
\hline \multicolumn{3}{|l|}{ Pteriomorphia } \\
\hline \multicolumn{3}{|l|}{ Mytiloida } \\
\hline Mytilus trossulus & $\mathrm{F}$ & DQ198231 \\
\hline Mytilus trossulus & M & DQ198225 \\
\hline Mytilus edulis & $\mathrm{F}$ & NC_006161 \\
\hline Mytilus edulis & M & AY823624 \\
\hline Mytilus galloprovincialis & $\mathrm{F}$ & NC_006886 \\
\hline Mytilus galloprovincialis & M & AY363687 \\
\hline \multicolumn{3}{|l|}{ Ostreoida } \\
\hline $\begin{array}{l}\text { Crassostrea } \\
\text { hongkongensis }\end{array}$ & - & NC_011518 \\
\hline Crassostrea gigas & - & NC_001276 \\
\hline Crassostrea virginica & - & NC_007175 \\
\hline Pectinoida & - & NC_009687 \\
\hline \multicolumn{3}{|l|}{ Argopecten irradians } \\
\hline $\begin{array}{l}\text { Placopecten } \\
\text { magellanicus }\end{array}$ & - & NC_007234 \\
\hline Mizuhopecten yessoensis & - & NC_009081 \\
\hline Chlamys farreri & - & NC_012138 \\
\hline Mimachlamys nobilis & - & NC_011608 \\
\hline \multicolumn{3}{|l|}{ Out-group } \\
\hline $\begin{array}{l}\text { Aplysia californica } \\
\text { (Gastropoda) }\end{array}$ & - & NC_005827 \\
\hline $\begin{array}{l}\text { Graptacme eborea } \\
\text { (Scaphopoda) }\end{array}$ & - & NC_006162 \\
\hline $\begin{array}{l}\text { Katharina tunicata } \\
\text { (Polyplacophora) }\end{array}$ & - & NC_001636 \\
\hline $\begin{array}{l}\text { Octopus vulgaris } \\
\text { (Cephalopoda) }\end{array}$ & - & NC_006353 \\
\hline $\begin{array}{l}\text { Platynereis dumerii } \\
\text { (Polychaeta) }\end{array}$ & - & NC_000931 \\
\hline
\end{tabular}

Having additional unionoid $\mathrm{F}$ and $\mathrm{M}$ genomes available for comparative analyses would also significantly illuminate investigations into the likely unique origin of DUI [26]. Analyses of morphological and molecular datasets indicate that unionoid bivalves, together with trigonioid bivalves, compose a monophyletic subclass, the Paleoheterodonta, [44-49]. The relative antiquity of this subclass within the Bivalvia is supported by the molecular sequence-based phylogenies, presented in Hoeh et al. ([45]: Figure three), Giribet and Wheeler ([47]: Figure five), Giribet and Distel ([48]: Figure three point five) and Dreyer and Steiner ([41]: Figure five), which suggest that the Paleoheterodonta are a product of an early cladogenic event in extant autolamellibranch ( suspension-feeding) bivalves. Given the hypothesized relatively basal position of unionoids in the bivalve phylogeny, their mt genomes could retain ancestral character states that are informative with respect to the initial $\mathrm{mt}$ genome duplication event (i.e., the formation of a distinct male-transmitted lineage in addition to a female-transmitted lineage) that led to the evolution of DUI.

In the present study, six new complete mitochondrial genomes, namely, the $\mathrm{F}$ and $\mathrm{M}$ genomes of the unionoid bivalves Venustaconcha ellipsiformis (Unionoida: Unionidae: Ambleminae: Lampsilini), Pyganodon grandis (Unionoida: Unionidae: Unioninae: Anodontini) and Quadrula quadrula (Unionoida: Unionidae: Ambleminae: Quadrulini), were compared with the available complete genomes of DUI species deposited in GenBank and their gene order, gene content and variation were analyzed. Additionally, complete bivalve mt genomes were phylogenetically analyzed to further test the hypothesized basal position of the Paleoheterodonta among extant autolamellibranch bivalves and to evaluate the evolutionary history of mitogenomic character state changes. The aim is to provide a context for comparisons of mt genomes among DUI and non-DUI bivalve lineages, and ultimately to identify the gene region(s) involved in the manifestation of DUI. Such descriptions and comparisons will contribute to a more complete picture of the evolution not only of the DUI system per $s e$, but also of the factors involved in the near universal presence of SMI in animals.

\section{Results}

\section{Phylogenetic analysis}

The majority-rule codon-based BI tree (Figure 1), derived from using concatenated sequences of mitochondrial protein-coding genes, is well resolved and very similar in topology to the best BI tree produced from analysis of amino acids as well as to the best nucleotide- and amino acid-based ML and parsimony trees (not shown). In summation, these trees clearly 


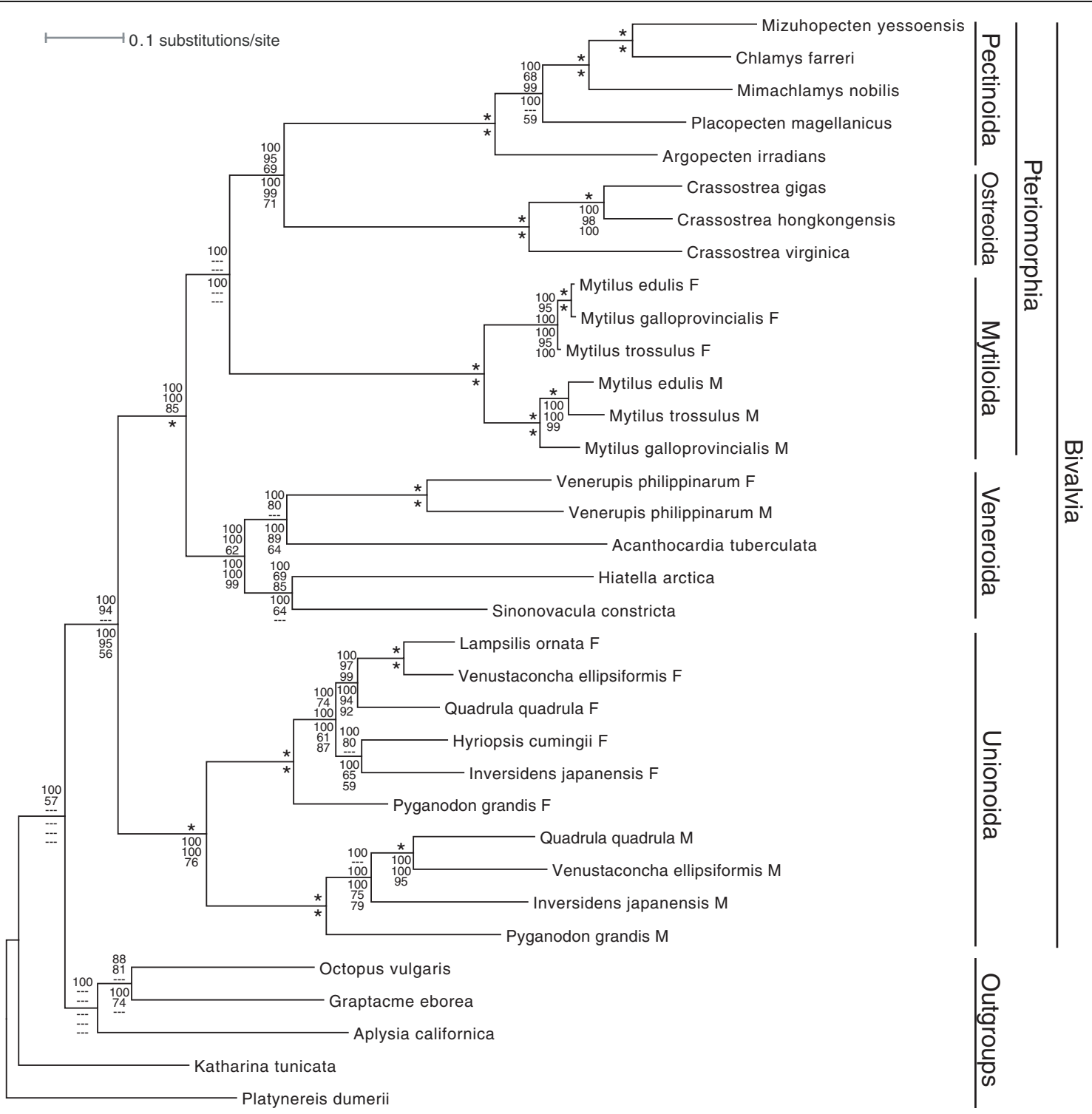

Figure 1 Bayesian inference majority-rule tree of bivalve $\mathrm{mt}$ genome relationships based on an analysis using the M3 codon substitution model and a nucleotide alignment of 12 mitochondrial protein-coding genes (atp8 excluded). Numbers above an internal branch, from top to bottom, indicate nodal support values from BI, ML and MP nucleotide-based analyses, respectively. Numbers below an internal branch, from top to bottom, indicate nodal support values from $\mathrm{Bl}, \mathrm{ML}$ and $\mathrm{MP}$ amino acid-based analyses, respectively. Only nodal support values $>50 \%$ are presented. An asterisk above an internal branch indicates that all three nucleotide-based nodal support values are 100; an asterisk below an internal branch indicates that all three amino acid-based nodal support values are 100. Branch lengths reflect substitutions per site and the taxonomic and gender-specific transmission affiliations of the individual sequences are indicated at the right. All phylogenetic analyses strongly indicate that the unionoids represent the basal lineage for the bivalve taxa represented in this analysis.

indicate that (1) the Bivalvia is monophyletic, (2) pteriomorph and veneroid bivalves are reciprocally monophyletic with unionoid bivalves being sister to Pteriomorphia+Veneroida, (3) the F and $\mathrm{M}$ clades in unionoids are reciprocally monophyletic and (4) branch lengths indicate the higher substitution rate of the unionoid $\mathrm{M}$ genome relative to that of the unionoid $\mathrm{F}$ genome. The ML reconstruction of the presence/ absence of DUI (Figure 2A), using the MK1 model, unambiguously indicates three origins of DUI for the taxa included in this study.

\section{Genome structural features}

The length of the F V. ellipsiformis, F P. grandis and F Q. quadrula mitochondrial genomes are $15,975 \mathrm{bp}, 15,848$ bp and 16,033 bp, respectively. These sizes are $\sim 950 \mathrm{bp}$ to 1,200 bp smaller than their $M$ counterparts whose genomes are 17,174 bp (V. ellipsiformis), 17,071 bp 


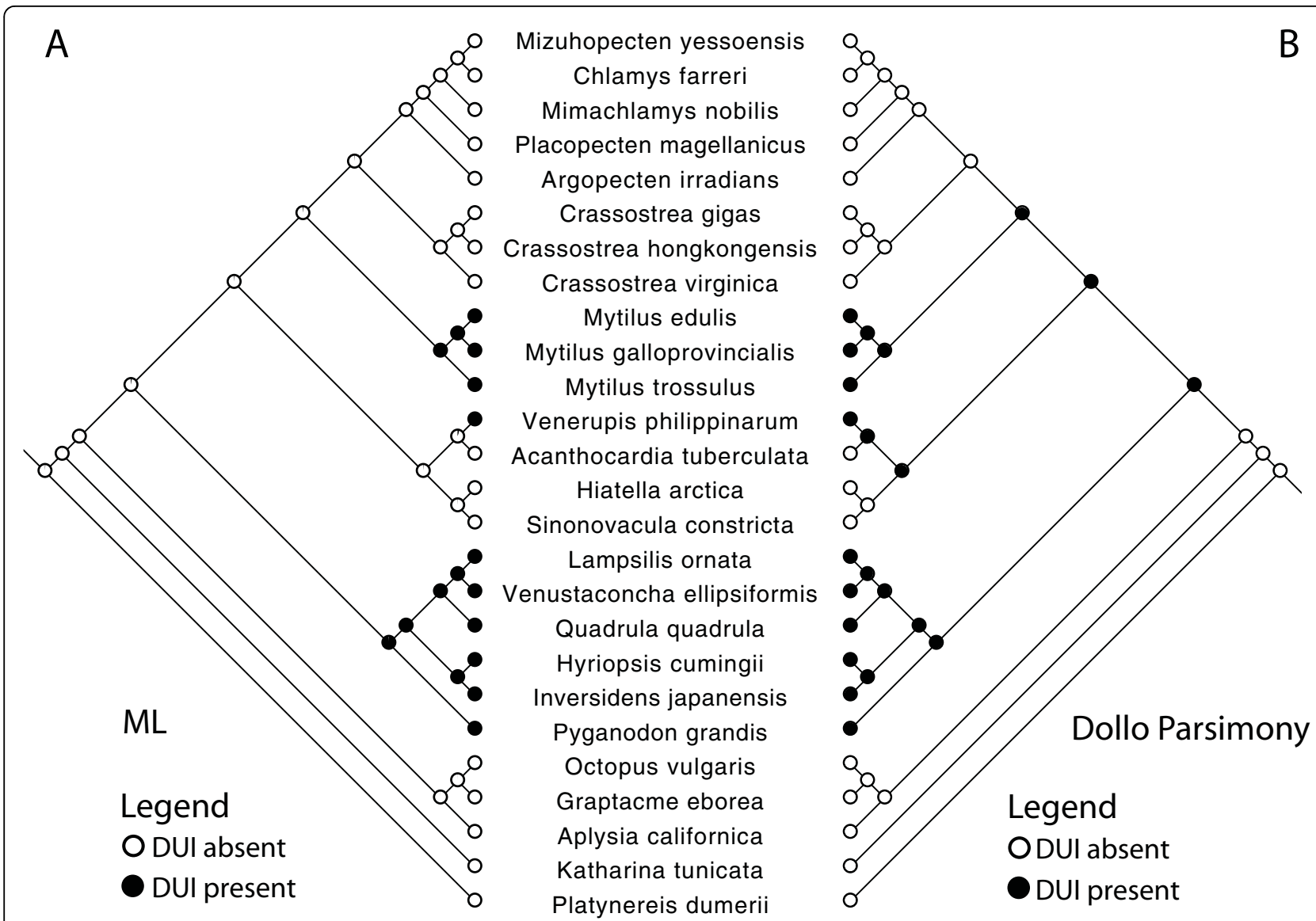

Figure $2 \mathrm{ML}$-based (A) and Dollo parsimony-based (B) ancestral character state reconstructions of presence/absence of DUI on a species-level tree derived from the tree presented in Figure 1. The ML-based reconstruction indicates three separate origins of DUI while the Dollo parsimony-based reconstruction indicates a single origin of DUI followed by three reversals to SMI.

(P. grandis) and 16,970 bp (Q. quadrula). The length differences are mainly due to the presence of a unique $M$ genome-specific 3' extension of the cytochrome $c$ oxidase subunit $2(\operatorname{cox} 2)$ gene and longer unassigned/noncoding regions in $\mathrm{M}$ genomes. The $\mathrm{A}+\mathrm{T}$ composition is very similar among the six newly sequenced genomes but higher than $\mathrm{F}$ and $\mathrm{M}$ I. japanensis (Table 2). Ribosomal RNA genes and protein-coding genes (except atp 8 ) of $\mathrm{M}$ and F genomes of $V$. ellipsiformis, $P$. grandis and $Q$. quadrula are arranged identically but tRNA order differs among the analyzed genomes (Figure 3). In unionoids, ten or eleven genes out of $\sim 37$ are located on one strand and all the other genes on the opposite (Figure 3).

\section{tRNA Histidine}

In the three newly sequenced $M$ genomes of this study, tRNA histidine $(\operatorname{trn} H)$ is positioned between $n d 5$ and $n d 1$ while in $\mathrm{F}$ genomes it is located between $n d 2$ and $n d 3$ (Figure 3). The location of the trnH gene in the I. japanensis $\mathrm{M}$ genome has previously been identified between $\operatorname{cox} 1$ and $\operatorname{cox} 2$ (Okazaki $\mathrm{M}$ and Ueshima R, personal communication). This location also corresponds to
Mcox2e. However, our reannotation of the I. japanensis $\mathrm{M}$ genome identifies $t r n H$ between $n d 5$ and $n d 1$ as in the three new $M$ genomes. Examination of 41 entire $\mathrm{mt}$ genomes across the Mollusca allows us to group some classes of mollusks according to the position of $\operatorname{trnH}$. For example, $\boldsymbol{n d 5 - t r n H - n d 4}$ (encoded on the heavy strand) is the common organization in the Cephalopoda while $n d 4-t r n H-n d 5$ (encoded on the light strand) and cox2trnG-trnH-trnQ-trnL2-atp8 (encoded on both strands) are two most common arrangements found in the Gastropoda. Except for unionoids genomes, no common arrangement is found in bivalves and the arrangement of the $t r n H$-containing region appears to be unique to each genus or species sequenced to date. Nd2-trnR-trnH-nd4 is found in the genus Crassostrea spp. (oysters) whereas the marine mussels Mytilus spp. possess the arrangement $n d 2$-trnR-trn W-trnA-trnS-trnH-trnP-nd3. Because of the current uncertainty regarding molluscan phylogeny, a rigorous ancestral character state reconstruction is not possible. However, the arrangement observed in Mytilus spp. could be an inversion (+ strand reversion) of the 
Table 2 Main structural features of the female- and male-transmitted mitochondrial genomes of Venustaconcha ellipsiformis, Pyganodon grandis, Inversidens japanensis and Quadrula quadrula.

\begin{tabular}{|c|c|c|c|c|c|c|c|c|}
\hline & $\begin{array}{l}V . \\
\text { ellipsiformis } \\
\text { Female }\end{array}$ & $\begin{array}{l}V . \\
\text { ellipsiformis } \\
\text { Male }\end{array}$ & $\begin{array}{l}\text { P. grandis } \\
\text { Female }\end{array}$ & $\begin{array}{l}\text { P. grandis } \\
\text { Male }\end{array}$ & $\begin{array}{l}\text { I. japanensis } \\
\text { Female }\end{array}$ & $\begin{array}{l}\text { I. japanensis } \\
\text { Male }\end{array}$ & $\begin{array}{l}\text { Q. quadrula } \\
\text { Female }\end{array}$ & $\begin{array}{l}\text { Q. quadrula } \\
\text { Male }\end{array}$ \\
\hline Total size & 15975 & 17174 & 15848 & 17071 & 16826 & 16966 & 16033 & 16970 \\
\hline \multicolumn{9}{|l|}{$\mathrm{pb}$} \\
\hline$A+T \%$ & 62.55 & 63.47 & 64.22 & 64.76 & 57.20 & 57.12 & 61.94 & 61.80 \\
\hline Strand - CG-skew & -0.46 & -0.49 & -0.36 & -0.33 & -0.42 & -0.41 & -0.48 & -0.51 \\
\hline Strand - AT-skew & -0.40 & -0.41 & -0.30 & -0.25 & -0.41 & -0.41 & -0.44 & -0.43 \\
\hline Strand + CG-skew & 0.32 & 0.31 & 0.28 & 0.25 & 0.26 & 0.30 & 0.33 & 0.38 \\
\hline Strand + AT-skew & -0.06 & 0.04 & -0.09 & -0.08 & 0.00 & 0.05 & -0.02 & 0.10 \\
\hline$r r n S$ & 865 & 859 & 847 & 841 & 844 & 864 & 857 & 865 \\
\hline$r r n L$ & 1271 & 1290 & 1271 & 1287 & 1304 & 1325 & 1297 & 1306 \\
\hline $\operatorname{cox} 1$ & $\begin{array}{l}1542 \\
(T T G / T A G)\end{array}$ & $\begin{array}{l}1537 \\
\left(\mathrm{GTG} / /^{* *}\right)\end{array}$ & $\begin{array}{l}1539 \\
(T T G / T A A)\end{array}$ & $\begin{array}{l}1537 \\
\left(\mathrm{CTG} / T^{* *}\right)\end{array}$ & $\begin{array}{l}1539 \\
(\mathrm{GTG} / \mathrm{TAA})\end{array}$ & $\begin{array}{l}1543 \\
\left(T T G / T^{* *}\right)\end{array}$ & $\begin{array}{l}1542 \\
\text { (TTG/TAG) }\end{array}$ & $\begin{array}{l}1534 \\
\left(\mathrm{GTG} / T^{* *}\right)\end{array}$ \\
\hline $\operatorname{cox} 2$ & $\begin{array}{l}684 \\
\text { (ATG/TAA) }\end{array}$ & $\begin{array}{l}1233 \\
\text { (ATG/TAA) }\end{array}$ & $\begin{array}{l}681 \\
\text { (ATG/TAG) }\end{array}$ & $\begin{array}{l}1251 \\
\text { (ATG/TAG) }\end{array}$ & $\begin{array}{l}681 \\
\text { (ATG/TAA) }\end{array}$ & $\begin{array}{l}1224 \\
\text { (ATG/TAG) }\end{array}$ & $\begin{array}{l}681 \\
\text { (ATG/TAG) }\end{array}$ & $\begin{array}{l}1230 \\
\text { (ATG/TAG) }\end{array}$ \\
\hline$N d 3$ & $\begin{array}{l}357 \\
\text { (ATG/TAG) }\end{array}$ & $\begin{array}{l}354 \\
\text { (ATG/TAA) }\end{array}$ & $\begin{array}{l}357 \\
\text { (ATG/TAA) }\end{array}$ & $\begin{array}{l}357 \\
(T T G / T A A)\end{array}$ & $\begin{array}{l}381 \\
\text { (ATG/TAA) }\end{array}$ & $\begin{array}{l}360 \\
\text { (ATG/TAG) }\end{array}$ & $\begin{array}{l}360 \\
\text { (ATA/TAA) }\end{array}$ & $\begin{array}{l}366 \\
\text { (ATT/TAA) }\end{array}$ \\
\hline$N d 2$ & $\begin{array}{l}972 \\
\text { (ATG/TAG) }\end{array}$ & $\begin{array}{l}957 \\
\text { (ATT/TAA) }\end{array}$ & $\begin{array}{l}966 \\
\text { (ATG/TAG) }\end{array}$ & $\begin{array}{l}972 \\
\text { (ATT/TAA) }\end{array}$ & $\begin{array}{l}960 \\
\text { (ATG/TAA) }\end{array}$ & $\begin{array}{l}981 \\
\text { (ATA/TAG) }\end{array}$ & $\begin{array}{l}966 \\
\text { (ATG/TAA) }\end{array}$ & $\begin{array}{l}990 \\
\text { (ATC/TAA) }\end{array}$ \\
\hline$c o b$ & 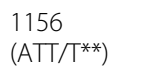 & $\begin{array}{l}1158 \\
\text { (ATG/TAA) }\end{array}$ & $\begin{array}{l}1146 \\
\text { (ATC/TAA) }\end{array}$ & $\begin{array}{l}1149 \\
(T T G / T A A)\end{array}$ & $\begin{array}{l}1152 \\
\text { (ATT/TAA) }\end{array}$ & $\begin{array}{l}1152 \\
(\text { GTG/TAA) }\end{array}$ & $\begin{array}{l}1152 \\
\text { (ATC/TAA) }\end{array}$ & $\begin{array}{l}1149 \\
\text { (ATG/TAA) }\end{array}$ \\
\hline Nd5 & $\begin{array}{l}1731 \\
\text { (ATA/TAA) }\end{array}$ & $\begin{array}{l}1758 \\
\text { (ATA/TAA) }\end{array}$ & $\begin{array}{l}1737 \\
(\mathrm{GTG} / \mathrm{TAG})\end{array}$ & $\begin{array}{l}1740 \\
\text { (ATA/TAA) }\end{array}$ & $\begin{array}{l}1704 \\
(\mathrm{GTG} / \mathrm{TAG})\end{array}$ & $\begin{array}{l}1765 \\
\left(T T A T^{* *}\right)\end{array}$ & $\begin{array}{l}1734 \\
\text { (ATG/TAA) }\end{array}$ & $\begin{array}{l}1770 \\
\text { (ATG/TAA) }\end{array}$ \\
\hline Nd1 & $\begin{array}{l}903 \\
(\mathrm{ATC} / \mathrm{TAA})\end{array}$ & $\begin{array}{l}903 \\
\text { (ATA/TAA) }\end{array}$ & $\begin{array}{l}900 \\
\text { (ATA/TAA) }\end{array}$ & $\begin{array}{l}897 \\
(\mathrm{GTG} / \mathrm{TAA})\end{array}$ & $\begin{array}{l}897 \\
\text { (ATC/TAG) }\end{array}$ & $\begin{array}{l}879 \\
\text { (ATA/TAA) }\end{array}$ & $\begin{array}{l}894 \\
\text { (ATA/TAA) }\end{array}$ & $\begin{array}{l}912 \\
\text { (ATG/TAA) }\end{array}$ \\
\hline Nd6 & $\begin{array}{l}489 \\
\text { (ATT/TAA) }\end{array}$ & $\begin{array}{l}456 \\
\text { (ATA/TAG) }\end{array}$ & $\begin{array}{l}489 \\
\text { (ATC/TAA) }\end{array}$ & $\begin{array}{l}405 \\
\text { (ATA/TAA) }\end{array}$ & $\begin{array}{l}489 \\
\text { (ATC/TAA) }\end{array}$ & $\begin{array}{l}528 \\
\text { (ATA/TAG) }\end{array}$ & $\begin{array}{l}498 \\
\text { (ATG/TAA) }\end{array}$ & $\begin{array}{l}522 \\
\text { (ATA/TAG) }\end{array}$ \\
\hline Nd4 & $\begin{array}{l}1347 \\
\text { (ATT/TAG) }\end{array}$ & $\begin{array}{l}1350 \\
\text { (ATG/TAG) }\end{array}$ & $\begin{array}{l}1344 \\
\text { (ATT/TAA) }\end{array}$ & $\begin{array}{l}1347 \\
(\text { GTG/TAA) }\end{array}$ & $\begin{array}{l}1374 \\
(\mathrm{GTG} / \mathrm{TAA})\end{array}$ & $\begin{array}{l}1362 \\
\text { (ATT/TAG) }\end{array}$ & $\begin{array}{l}1332 \\
(T T / T A A)\end{array}$ & $\begin{array}{l}1380 \\
\text { (ATG/TAA) }\end{array}$ \\
\hline$N d 4 I$ & $\begin{array}{l}297 \\
\text { (GTG/TAG) }\end{array}$ & $\begin{array}{l}297 \\
(T T G / T A A)\end{array}$ & $\begin{array}{l}297 \\
\text { (GTG/TAG) }\end{array}$ & $\begin{array}{l}264 \\
\text { (ATA/TAG) }\end{array}$ & $\begin{array}{l}297 \\
\text { (GTG/TAA) }\end{array}$ & $\begin{array}{l}309 \\
\text { (ATA/TAG) }\end{array}$ & $\begin{array}{l}294 \\
\text { (GTG/TAG) }\end{array}$ & $\begin{array}{l}297 \\
\text { (ATG/TAG) }\end{array}$ \\
\hline atp8 & $\begin{array}{l}210 \\
\text { (GTG/TAA) }\end{array}$ & $\begin{array}{l}174 \\
\text { (GTG/TAG) }\end{array}$ & $\begin{array}{l}225 \\
\text { (ATG/TAA) }\end{array}$ & Remnant & $\begin{array}{l}\text { Remnant } 96 \\
\text { (GTG/TAG) }\end{array}$ & $\begin{array}{l}181 \\
\left(\mathrm{ATG} / T^{* *}\right)\end{array}$ & $\begin{array}{l}159 \\
(\text { ATG/TAA) }\end{array}$ & $\begin{array}{l}123 \\
(\mathrm{GTG} / \mathrm{TAA})\end{array}$ \\
\hline atp6 & $\begin{array}{l}708 \\
\text { (ATG/TAG) }\end{array}$ & $\begin{array}{l}696 \\
\text { (ATG/TAA) }\end{array}$ & $\begin{array}{l}714 \\
\text { (ATG/TAG) }\end{array}$ & $\begin{array}{l}690 \\
\text { (ATG/TAA) }\end{array}$ & $\begin{array}{l}708 \\
(\text { ATG/TAG) }\end{array}$ & $\begin{array}{l}663 \\
\text { (ATG/TAG) }\end{array}$ & $\begin{array}{l}708 \\
\text { (ATG/TAG) }\end{array}$ & $\begin{array}{l}678 \\
\text { (ATA/TAG) }\end{array}$ \\
\hline $\operatorname{cox} 3$ & $\begin{array}{l}780 \\
\text { (ATG/TAG) }\end{array}$ & $\begin{array}{l}774 \\
(\mathrm{ATT/TAA)}\end{array}$ & $\begin{array}{l}780 \\
\text { (ATG/TAA) }\end{array}$ & $\begin{array}{l}772 \\
\left(A T G / T^{* *}\right)\end{array}$ & $\begin{array}{l}795 \\
\text { (ATA/TAA) }\end{array}$ & $\begin{array}{l}810 \\
(\mathrm{GTG} / \mathrm{TAA})\end{array}$ & $\begin{array}{l}780 \\
\text { (ATG/TAG) }\end{array}$ & $\begin{array}{l}777 \\
(\mathrm{ATT/TAA)}\end{array}$ \\
\hline
\end{tabular}

NOTE.- Gene lengths are in bp. For each protein-coding gene, start and stop codons are presented in parentheses.

nd3-trnH-trnA-trnS1-trnS2-nd2 observed in the unionoid $\mathrm{F}$ genomes. In the four unionoid $\mathrm{M}$ genomes, $\operatorname{trnH}$ is located between $n d 5$ and $n d 1$ and the only other molluscan species with a similar location for its $\operatorname{trnH}$ (i.e., $n d 5$ trnL-trnH-nd1) is the patellogastropod limpet Lottia digitalis. The gene order of the $L$. digitalis $m t$ genome is the most divergent among all gastropod mtDNAs sequenced thus far [50].

\section{Extension of the $M$ cytochrome c oxidase subunit II gene}

The three analyzed $M$ genomes possess the unique 3' extension of the cytochrome $c$ oxidase subunit II gene (Mcox2e) [22]. In the three newly sequenced $M$ genomes, the extension is 187 codons ( $V$. ellipsiformis and $P$. grandis) or 186 codons (Q. quadrula) in length while the I. japanensis extension is slightly shorter with 181 codons.

\section{Atp8 gene}

As in the F genome of L. ornata [37] and the reannotated $\mathrm{F}$ and $\mathrm{M}$ genomes of I. japanensis [2], the newly sequenced $\mathrm{F}$ and $\mathrm{M}$ genomes contain the 13 protein-coding genes commonly found in other animal mtDNAs. Only the $M$ genome of $P$. grandis appears to lack a complete atp8. In this species, a remnant of the atp 8 gene that corresponds to the first 15 amino acids (MPQLSPVYWVSIFFL) of the protein, and that shows similarities with other atp 8 genes sequenced in this study, has been identified between $\operatorname{trn} D$ and $\operatorname{atp} 6$ (Figure 3). Those 15 amino acids are followed by a complete stop codon. After the stop codon, we also identified an open reading frame, in a different frame than the first 15 amino acids, which could correspond to the remainder of $\operatorname{atp} 8$. 

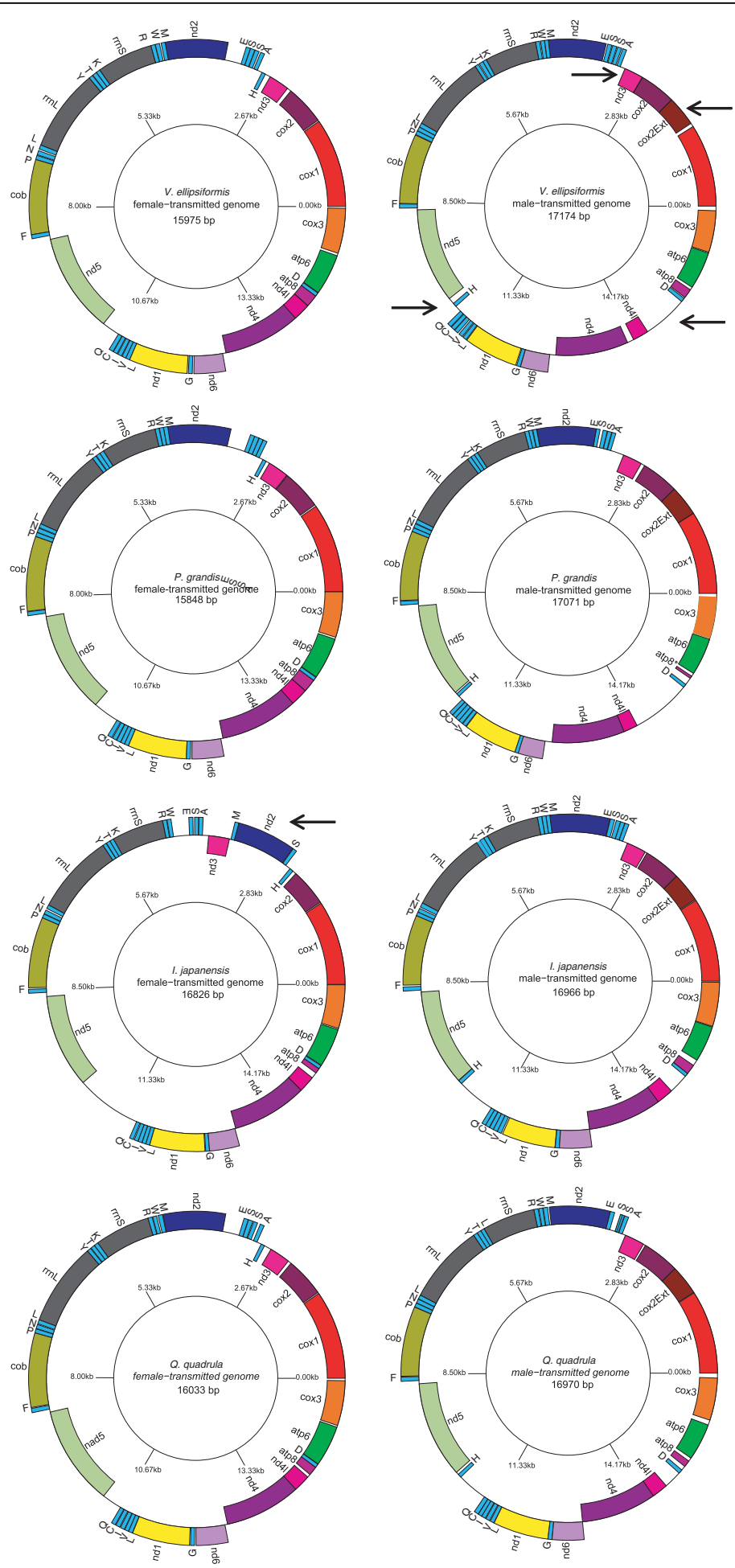

Figure 3 Gene maps of the M and F mitochondrial genomes of Venustaconcha ellipsiformis, Pyganodon grandis, Inversidens japanensis and Quadrula quadrula. Protein and rRNA genes are named as in the text while tRNA genes are abbreviated by the one-letter code of the corresponding amino acid ( $\mathrm{L} 1=\operatorname{trn} \mathrm{L}(\mathrm{cua}), \mathrm{L} 2=\operatorname{trn} \mathrm{L}$ (uaa), $\mathrm{S} 1=\operatorname{trnS}(\mathrm{aga})$, and $\mathrm{S} 2=\operatorname{trn} \mathrm{S}$ (uaa)). Genes positioned inside the plain line are encoded on the heavy strand and genes outside the line are encoded on the light strand. Atp $8^{*}$ (= genomes lacking full size atp8 gene). Black arrows on the $\mathrm{V}$. ellipsiformis $\mathrm{M}$ genome indicate regions that differ between male- and female-transmitted genomes and the arrow on the $\mathrm{I}$. japanensis $\mathrm{F}$ genome indicates the region with a gene order distinct from that of the other figured $\mathrm{F}$ genomes. The circular gene maps of the genomes were drawn by GenomeVx [113] followed by manual modification. 


\section{$N A D H$ dehydrogenase subunits 4 and $4 L$ genes}

Most unionoid $\mathrm{mt}$ genomes examined in this study have an overlap of $7 \mathrm{bp}$ for subunits 4 and $4 \mathrm{~L}$ of the NADH dehydrogenase complex ( $n d 4$ and $n d 4 l$ ). Two exceptions are the $\mathrm{M}$ genome of $V$. ellipsiformis, which contains a noncoding region of $120 \mathrm{bp}$ between $n d 4$ and $n d 4 l$, and the $\mathrm{F}$ genome of I. japanensis, which possesses one nucleotide between those two genes.

\section{Base composition and codon usage}

The base composition bias of an individual strand can be described by skewness [51], where CG-skew $=(C$ $\mathrm{G}) /(\mathrm{C}+\mathrm{G})$ and AT-skew $=(\mathrm{A}-\mathrm{T}) /(\mathrm{A}+\mathrm{T})$. The strand encoding most of the proteins (including cox 1 ) from the $\mathrm{F}$ and $\mathrm{M}$ genomes of all unionoid species has strong negative CG- and AT-skews (Table 2). Skews calculated for the opposite strand in all six genomes indicate complementary strand bias, with positive CG- and AT-skew values (Table 2), an expected result since, for example, A-skew on one strand is usually balanced by T-skew on the other [52].

\section{Transfer RNA genes}

In all eight unionoid $\mathrm{mt}$ genomes, we identified all 22 tRNA genes according to their secondary structure features and their corresponding anticodons. Most have the potential to fold into a normal cloverleaf structure, although some do not have paired DHU arms, and a few others have mismatched bp. The putative cloverleaf secondary structures of unionoid tRNAs are available in the additional files (Additional file 1, Figures S1, S2, S3, S4, S5, S6, S7 and S8). The tRNA genes are $\sim 60-70 \mathrm{bp}$ long and the mean GC content varies between $35.2 \%$ and $37.4 \%$. In the eight mt genomes, most of the tRNA genes are located on the light strand; only trnH (Histidine) and $\operatorname{trn} D$ (Aspartate) are located on the heavy strand along with most of the protein-coding genes. As specified earlier, trnH has distinct localizations in $\mathrm{F}$ and $\mathrm{M}$ unionoid genomes (Figure 3). For all $\mathrm{mt}$ genomes (except M I. japanensis), the DHU arm of trnS1 (Serine) is unpaired. Unpaired DHU arms are also observed for the second Serine trnS2 (tct) and Threonine $\operatorname{trnT}$ in the $M$ genome of $P$. grandis, for the Arginine $\operatorname{trn} R$ and
Threonine trnT in the $\mathrm{M}$ genome of $V$. ellipsiformis and for the Cysteine $\operatorname{trn} C$ and Threonine trnT in the $\mathrm{M}$ genome of Q. quadrula. DHU arm for the Lysine trnK in the F genome of Q. quadrula is also unpaired. No unpaired DHU arm has been observed in tRNAs of M $I$. japanensis.

\section{Unassigned regions and putative control regions}

Twenty-two or thirty-three unassigned regions were detected in the six genomes, with sizes ranging from 1 to $1196 \mathrm{bp}$. The three newly sequenced $\mathrm{F}$ genomes present a more compact arrangement than the three $M$ genomes (Table 3). We observed the opposite trend in $I$. japanensis where the $\mathrm{F}$ genome contains more unassigned sequences (12.9\% of the genome) than the $M$ genome ( $8.9 \%$ of the genome). The abundance of unassigned sequences in both $\mathrm{F}$ and $\mathrm{M}$ genomes of the four unionoid species analyzed here is similar with the results observed in their mytiloid $\mathrm{F}$ and $\mathrm{M}$ counterparts $(\sim 10 \%$ of unassigned sequences) $[31,34,36]$. In comparison, the veneroid clam $V$. philippinarum $\mathrm{M}$ and $\mathrm{F}$ genomes have a higher proportion of unassigned sequences (i.e., > $15.8 \%$ for $\mathrm{F}$ and $>21.3 \%$ for M) (Okazaki M, Ueshima $\mathrm{R}$, personal communication).

\section{Levels of intra- and interspecies sequence divergences}

Table 4 contains Intra- and interspecific comparisons of the concatenated nucleotide and amino acid sequences of 12 protein-coding genes (atp 8 has been excluded and only species for which both $\mathrm{F}$ and $\mathrm{M}$ genomes are available were used) from the M- and F-transmitted mitochondrial genomes of unionoid bivalves. The smallest nucleotide and amino acid distances are observed between the two F genomes of the most closely-related species, i.e. V. ellipsiformis and Q. quadrula (P of 0.207 and $\mathrm{P}(\mathrm{aa})$ of 0.157$)$. Overall, nucleotide and amino acid sequence divergences between all pairs of $\mathrm{F}$ genomes are considerably lower than between $\mathrm{M}$ pairs or between the $\mathrm{M}$ and $\mathrm{F}$ genomes of the same species. Early estimations of the nucleotide divergence between $\mathrm{M}$ and $\mathrm{F}$ genomes of unionoid bivalves were based on p-distances of partial $\operatorname{cox} 1$ sequences [20] and were around 28 to $33 \%$. Our results show that these early estimations were

Table 3 Unassigned regions of the female- and male-transmitted mitochondrial genomes of Venustaconcha ellipsiformis, Pyganodon grandis, Inversidens japanensis and Quadrula quadrula.

\begin{tabular}{|c|c|c|c|c|c|c|c|c|}
\hline & $\begin{array}{l}V . \\
\text { ellipsiformis } \\
\text { Female }\end{array}$ & $\begin{array}{l}\text { V. } \\
\text { ellipsiformis } \\
\text { Male }\end{array}$ & $\begin{array}{l}P . \\
\text { grandis } \\
\text { Female }\end{array}$ & $\begin{array}{l}P . \\
\text { grandis } \\
\text { Male }\end{array}$ & $\begin{array}{l}\text { I. } \\
\text { japanensis } \\
\text { Female }\end{array}$ & $\begin{array}{l}\text { I. } \\
\text { japanensis } \\
\text { Male }\end{array}$ & $\begin{array}{l}\text { Q. } \\
\text { quadrula } \\
\text { Female }\end{array}$ & $\begin{array}{l}\text { Q. } \\
\text { quadrula } \\
\text { Male }\end{array}$ \\
\hline Unassigned regions & 27 & 33 & 24 & 27 & 27 & 22 & 29 & 28 \\
\hline Total (bp) & 1310 & 1828 & 1178 & 2025 & 2177 & 1516 & 1366 & 1583 \\
\hline Proportion of the genome (\%) & 8.2 & 10.6 & 7.3 & 11.9 & 12.9 & 8.9 & 8.5 & 9.3 \\
\hline Largest NC region (bp) & 308 & 833 & 480 & 1103 & 1196 & 698 & 346 & 555 \\
\hline
\end{tabular}


Table 4 Intra- and interspecies comparisons for 12 mitochondrial protein-coding genes: average pairwise sequence divergence

\begin{tabular}{|c|c|c|c|c|c|c|c|c|c|c|}
\hline Pairs & $\mathbf{P}$ & $\mathrm{K} 2 \mathrm{P}$ & JC & TrN & $\mathrm{Na}$ & $\mathrm{P}(\mathrm{aa})$ & D & $\mathrm{K}_{\mathrm{a}}$ & $\mathrm{K}_{\mathrm{s}}$ & $\mathrm{K}_{\mathrm{a}} / \mathrm{K}_{\mathrm{s}}$ \\
\hline \multicolumn{11}{|l|}{$F \times F$} \\
\hline VenF $\times$ PygF & 0.248 & 0.306 & 0.301 & 0.311 & 434 & 0.192 & 0.214 & 0.137 & 1.400 & 0.098 \\
\hline VenF $\times \operatorname{lnvF}$ & 0.249 & 0.307 & 0.302 & 0.312 & 431 & 0.191 & 0.212 & 0.137 & 1.358 & 0.101 \\
\hline VenF $\times$ QuaF & 0.207 & 0.246 & 0.242 & 0.251 & 353 & 0.157 & 0.170 & 0.101 & 1.010 & 0.100 \\
\hline PygF $\times \operatorname{InvF}$ & 0.274 & 0.346 & 0.340 & 0.353 & 488 & 0.216 & 0.244 & 0.157 & 1.785 & 0.088 \\
\hline PygF $\times$ QuaF & 0.252 & 0.312 & 0.317 & 0.318 & 466 & 0.207 & 0.231 & 0.147 & 1.350 & 0.109 \\
\hline $\operatorname{lnvF} \times \mathrm{QuaF}$ & 0.247 & 0.303 & 0.308 & 0.308 & 466 & 0.207 & 0.231 & 0.144 & 1.213 & 0.119 \\
\hline \multicolumn{11}{|l|}{$M \times M$} \\
\hline VenM $\times$ PygM & 0.370 & 0.514 & 0.510 & 0.529 & 950 & 0.421 & 0.496 & 0.353 & 1.548 & 0.228 \\
\hline VenM $\times$ InvM & 0.340 & 0.459 & 0.454 & 0.468 & 865 & 0.384 & 0.484 & 0.300 & 1.352 & 0.222 \\
\hline VenM $\times$ QuaM & 0.303 & 0.393 & 0.389 & 0.402 & 796 & 0.353 & 0.435 & 0.272 & 0.946 & 0.288 \\
\hline PygM × InvM & 0.372 & 0.522 & 0.514 & 0.533 & 882 & 0.391 & 0.496 & 0.327 & 2.093 & 0.156 \\
\hline PygM × QuaM & 0.374 & 0.522 & 0.518 & 0.536 & 933 & 0.414 & 0.534 & 0.360 & 1.523 & 0.236 \\
\hline InvM × QuaM & 0.340 & 0.458 & 0.454 & 0.465 & 836 & 0.371 & 0.463 & 0.307 & 1.241 & 0.247 \\
\hline \multicolumn{11}{|l|}{$\mathrm{F} \times \mathrm{M}$} \\
\hline VenF $\times$ VenM & 0.407 & 0.586 & 0.586 & 0.603 & 1135 & 0.503 & 0.700 & 0.474 & 1.112 & 0.426 \\
\hline PygF $\times$ PygM & 0.428 & 0.636 & 0.634 & 0.657 & 1142 & 0.506 & 0.706 & 0.494 & 1.428 & 0.346 \\
\hline $\operatorname{lnvF} \times \operatorname{InvM}$ & 0.430 & 0.641 & 0.638 & 0.653 & 1139 & 0.505 & 0.703 & 0.482 & 1.523 & 0.316 \\
\hline QuaF × QuaM & 0.419 & 0.625 & 0.614 & 0.632 & 1164 & 0.516 & 0.726 & 0.500 & 1.142 & 0.438 \\
\hline
\end{tabular}

NOTE. -P, uncorrected nucleotide divergence; K2P, nucleotide divergence with Kimura's -parametertwo model; JC, nucleotide divergence with Jukes and Cantor model; TrN, nucleotide divergence with Tamura-Nei model; $\mathrm{Na}$, total number of amino acid differences; $\mathrm{P}(\mathrm{aa})$, uncorrected amino acid p-distances; $\mathrm{D}$, Poissoncorrected amino acid distances, and estimates of $\mathrm{K}_{\mathrm{a}}$ (the number of nonsynonymous substitutions per nonsynonymous site) and $\mathrm{K}_{\mathrm{s}}(\mathrm{t}$ he number of synonymous substitutions per synonymous site) using the Jukes and Cantor (1969) correction. VenF: Venustaconcha ellipsiformis $\mathrm{F}$ genome; PygF: Pyganodon grandis $\mathrm{F}$ genome; InvF: Inversidens japanensis F genome; QuaF: Quadrula quadrula F genome; VenM: V. ellipsiformis M genome; PygM: P. grandis M genome; InvM: I. japanensis M genome; QuaM: Q. quadrula M genome.

conservative and the average uncorrected divergence between the $\mathrm{F}$ and $\mathrm{M}$ concatenated nucleotide sequences for the 12 mitochondrial protein-coding genes is $41 \%$ for $V$. ellipsiformis, $42 \%$ for Q. quadrula and $43 \%$ for $P$. grandis and I. japanensis. These very high intraspecific divergences are observed at both the DNA and protein levels (Table 4).

\section{Discussion}

\section{Phylogenetic analysis}

The seemingly anomalous difference in branching pattern between the $\mathrm{M}$ and $\mathrm{F}$ Mytilus genomes is due to an asymmetric introgression of $M$. edulis $M$ mtDNA into the Baltic $M$. trossulus [36]. Nevertheless, the ingroup (= bivalves) topology in Figure 1 is consistent with other sequence-based phylogenetic reconstructions in that the Unionoida is basal to Pteriomorphia+Veneroida (e.g., $[41,45,48])$ thus reinforcing the hypothesis that the Unionoida is a relatively ancient bivalve lineage potentially harboring the ancestral characteristics of DUI.

Although the phylogenetic hypothesis ((Pteriomorphia, Veneroida) Unionoida) is not typically portrayed as the best estimate of evolutionary relationships for these lineages at this time (e.g., [53]: Figure six point height), the statistical robustness of our phylogenetic analyses with regards to the Bivalvia (Figure 1) indicates that it should be seriously evaluated in future, higher level bivalve phylogenetic studies.

The three origins of DUI for the taxa included in this study (Figure 2A) runs counter to the prevailing hypothesis of a single origin for this complex trait with subsequent reversals to SMI [23,26-28] but it is not unexpected given the bias toward "DUI absence" stemming from the difficulties in confirming the presence of DUI (e.g., $[20,25,26,54])$. The complexity of the cytonuclear interactions involved in DUI and its very narrow taxonomic distribution are consistent with the hypothesis that the gain of DUI is a relatively rare event with subsequent losses being potentially more common. If a low ratio of rate of DUI gain to rate of DUI loss actually holds, then the use of the Dollo parsimony model $[55,56]$ is more appropriate than the use of the MK1 model and the former indicates a single gain of DUI with three subsequent losses (Figure 2B). A much more accurate understanding of the actual taxonomic distribution of DUI combined with a taxonomically expanded version of our robustly supported bivalve phylogeny (Figure 1) would allow a rigorous evaluation of the single vs. multiple origins of DUI hypotheses as well as the rates of DUI gain vs. loss. 


\section{Genome structural features}

Overall, the most notable differences observed between $\mathrm{M}$ and $\mathrm{F}$ unionoid genomes are (i) the position of $\operatorname{trnH}$, (ii) an inversion of the $\operatorname{trn} D$ and $a t p 8$ genes, (iii) the length of the $\operatorname{cox} 2$ gene (the $M$ genomes possess a 3' extension of $\operatorname{cox} 2$ ) as well as (iv) a noncoding region between $n d 4$ and $n d 4 l$ in the M mtDNA genome of $V$. ellipsiformis (Figure 3). The female-transmitted mtDNAs of $V$. ellipsiformis, P. grandis and Q. quadrula are comparable in many respects to the F mtDNA of $L$. ornata, which is unique in gene arrangement relative to all other molluscan and metazoan mt genomes [37]. The mitochondrial gene order rearrangement in the $\mathrm{F}$ genomes of $I$. japanensis and $H$. cumingii (Unionoida: Unionidae: Ambleminae: Gonideini), i.e. the relative positions of the $n d 2$, trnM to $n d 3$ genes, appear to be unique to the Gonideini as neither L. ornata, V. ellipsiformis (Unionidae: Unionidae: Ambleminae: Lampsilini), Q. quadrula (Unionoida: Unionidae: Ambleminae: Quadrulini) nor P. grandis (Unionidae: Unionidae: Unioninae: Anodontini) show this rearrangement. We suggest that this distinct gene order in the $\mathrm{F}$ genomes of I. japanensis and H. cumingii resulted from a tandem duplication of the gene region followed by the deletion of segments of the duplicated gene region. Losses and gains of genes, gene rearrangements and unusually large amounts of duplicated or noncoding nucleotides are common in mollusk mitochondrial genomes $[39,57,58]$.

When looking across other complete bivalve genomes, which include species from the orders Pectinoida, Ostreoida, Veneroida and Mytiloida (Organellar Genome Retrieval database OGRe; [59]), all genes are characteristically on the same strand (Figure 4A). Among the Bivalvia, only in unionoids are the genes transcribed in both directions. Robust phylogenies are necessary to compare bivalve mt genome arrangements in an evolutionary context and our understanding of the phylogenetic relationships among the major lineages within the Bivalvia and among molluscan classes is still limited and controversial [60]. Nonetheless, based on bivalve phylogenetic analyses presented in Hoeh et al. [45], Giribet and Distel [48], Dreyer and Steiner [41] and herein (Figure 1), the "all-on-one-strand" phenotype likely represents a shared, derived characteristic that evolved once in the common ancestor of the Pteriomorphia and Veneroida with the unionoid model of genes on different strands representing the ancestral state for the Bivalvia (Figure 4A).

\section{tRNA Histidine}

While the gene boundary $\underline{n d 3-\operatorname{trH}}$ on the heavy strand observed in unionoid $\mathrm{F}$ genomes is not shared by any other mollusk taxon studied so far, the gene boundary $n d 5$ - $\operatorname{trn} H$ observed in the four unionoid $\mathrm{M}$ genomes is also shared by nine species of cephalopods, the polyplacophoran Katharina tunicata and the gastropod Haliotis rubra. This particular gene boundary could represent the ancestral character state for the Mollusca. The tRNA genes are the most evolutionarily mobile elements of the animal mitochondrial genome and variation in mitochondrial tRNA gene organization have been found in multiple divergent taxa [61,62]. Rearrangement of tRNAs occurs frequently because their secondary structure facilitates their translocation [63]; alternatively, rearrangements can also result from a duplication event [64].

\section{Extension of the M cytochrome c oxidase subunit II gene}

All unionoid bivalve $M$ genomes examined to date contain an Mcox2e region [25], which is not present in other DUI-possessing bivalve lineages nor, apparently, in any other animal mitochondrial genomes [43]. Structural characterization of the MCOX2e region predicted the presence of an interspecifically variable number of transmembrane helices [43], and immunohistochemistry- and immunoelectronmicroscopy-based analyses revealed that MCOX2e is expressed in sperm mitochondria [65] and is sub-cellularly localized to both inner and outer mitochondrial membranes [16]. The latter localization, which possibly "tags" the outer surface of unionoid M genomebearing mitochondria, could facilitate the differential segregation of the $\mathrm{M}$ genome-containing $\mathrm{mt}$, derived from the fertilizing sperm, in male and female embryos (as observed in Mytilus; [66,67]). Consistent with the above, seasonal variation in expression profiles suggest that unionoid $\mathrm{MCOX} 2 e$ functions in reproduction $[16,43,64]$.

\section{Atp8 gene}

In animal mtDNAs, the atp 8 gene is the smallest protein-coding gene $(\approx 50$ to 65 aa) with only a few highly conserved amino acid residues. It encodes a protein subunit of the $F_{0}$ portion of the mitochondrial ATP synthase, which is the enzymatic complex that drives the phosphorylation of ADP to ATP. The ATP synthase comprises the $F_{1}$ catalytic domain situated in the mitochondrial matrix and the $F_{0}$ proton pore embedded in the mitochondrial inner membrane. Although the specific function of ATP8 is not yet known, in yeast, it is thought to play an important role in the assembly of the $\mathrm{F}_{0}$ portion of ATP synthase and in determining ATP synthase activity (reviewed in [68]). In mammals, it is the most rapidly evolving mitochondrial protein-coding gene [69]. Atp 8 has been lost independently from the $\mathrm{mt}$ genomes of several lineages including some bivalves [e.g., marine mussels possessing DUI $[31,34,36]$ and oysters [70], secernentean nematodes [71], and platyhelminths [72]. Interestingly, all other mollusk species (i.e., gastropods, cephalopods, polyplacophorans and scaphopods) studied to date possess an atp 8 gene $[2,70]$. The $\mathrm{F}$ and $M$ genomes of the marine clam Venerupis 


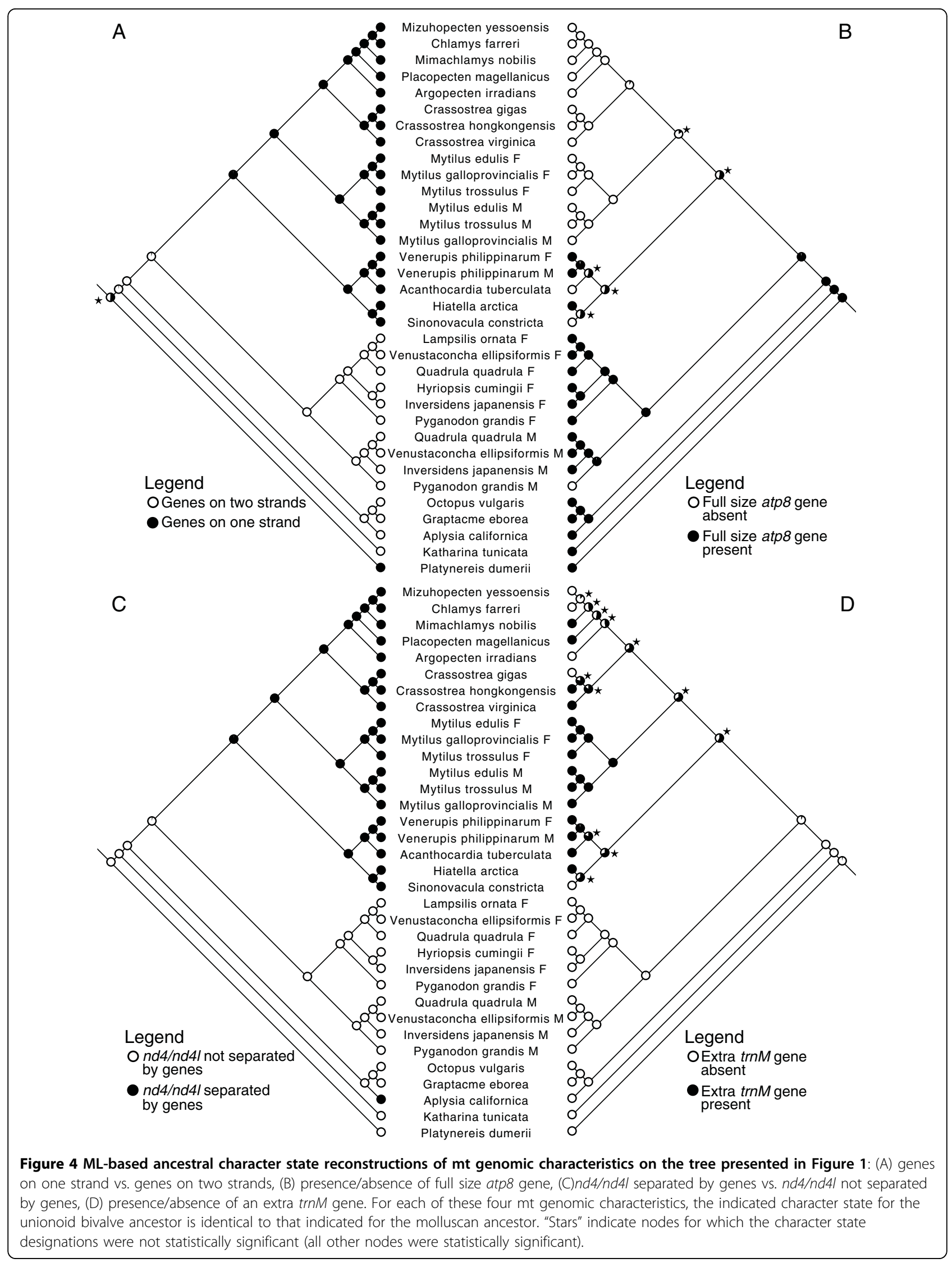


philippinarum also possess a short putative atp 8 gene (37 aa; [41]) and a potential remnant of the atp 8 gene has been found in the eastern oyster Crassostrea virginica [40]. These observations and the phylogeny displayed in Figure 1 reinforce the hypothesis that unionoid $\mathrm{mt}$ genomes possess the molluscan ancestral character state ( $=$ the presence of atp 8 ) and that two losses of atp 8 in veneroids and another in the common ancestor of the Pteriomorphia could have occurred during bivalve phylogenesis (Figure 4B). In the $\mathrm{M}$ genome of $P$. grandis, even though we identified an open reading frame that corresponds to a portion of atp 8 , the complete stop codon early in the sequence could yield a non-functional protein. Further analysis will be necessary to confirm or refute the existence of a functional atp 8 in the $\mathrm{M}$ genome of this species. For now, the presence/absence of atp 8 seems extremely labile across bivalve taxa, but this phenomenon does not appear to be related to the presence/absence of doubly uniparental inheritance.

\section{$N A D H$ dehydrogenase subunits 4 and $4 L$ genes}

NADH dehydrogenase subunits 4 and $4 \mathrm{~L}$ genes generally overlap or are adjacent to one another in animal $\mathrm{mt}$ genomes [57,73]. This is also the case for most unionoid $\mathrm{mt}$ genomes examined in this study except for the $M$ genome of $V$. ellipsiformis where those genes are separated by a large noncoding region as well as for the $\mathrm{F}$ genome of I. japanensis, where both genes are separated by one nucleotide. We cannot exclude the possibility that this single nucleotide in the F I. japanensis sequence represents a sequencing error.

In vertebrates $n d 4$ and $n d 4 l$ are transcribed as one bicistronic mRNA, and are therefore localized together [73]. Moreover, in several mollusks (i.e., one scaphopod, some gastropods and all 12 cephalopods studied to date (Organellar Genome Retrieval database OGRe; [59]), these two genes are also adjacent to one another or overlap. However, in all other non-unionoid bivalve species studied to date ( 7 genera), $n d 4$ and $n d 4 l$ have several intervening coding genes (e.g., Crassostera gigas [40] and Hiatella arctica [41]). Again, the overlap observed between $n d 4-n d 4 l$ in most of the new unionoid genomes analyzed herein and the phylogeny displayed in Figure 1 support the hypothesis that unionoid $\mathrm{mt}$ genomes possess the molluscan ancestral character state and that the derived state, "intervening genes", occurred once in the common ancestor of pteriomorph and veneroid bivalves (Figure 4C).

\section{Base composition and codon usage}

Although the exact mechanisms responsible for creating CG- and AT-skews like those observed in this study are still poorly understood, it is most likely created by the biases in mutational pressure owing to differences in the time spent as single-stranded DNA during both transcription and replication [74]). The negative CG- and AT-skews observed in the strand that encodes most of the proteins (i.e., cox 1 - cox 3 - atp 6 - atp 8 - nd4L - nd4 - nd5 - nd3 - cox2 (Mcox 2e)) and that make it G+T rich is reflected in the use of synonymous codons (Additional file 2, Table S1). This is particularly evident at the third codon positions of protein-coding genes where Cand A-ending codons are used less frequently. Overall, TTT (Phe), TTG (Leu) and TTA (Leu) are the most frequent codons, a result consistent with other invertebrate mtDNAs [34]. Except for the stop codons TAA and TAG, TGC, CGC and ACG are among the least used codons. Of these, CGC is also the least common codon in the mtDNA of other mollusks [34].

\section{Transfer RNA genes}

Interestingly, unionoid bivalves do not possess an extra $\operatorname{trn} M$, a situation that is present in both pteriomorph and veneroid bivalves $[2,31,34]$. The presence of an extra trnM within the latter two lineages could represent a character state that was (1) independently derived multiple times, (2) derived once with multiple independent secondary losses or (3) both derived and lost multiple times independently (Figure 4D). The absence of a second trnM in all other molluscan species studied to date [2] reinforces the hypothesis that unionoids likely possess the molluscan ancestral character state for this character (Figure 4D).

\section{Unassigned regions and putative control regions}

The presence of multiple unassigned regions is not uncommon in mollusk mitochondrial genomes $[75,76]$ and is usually suggestive of molecular rearrangements [77]. The large unassigned region located between $n d 5$ and $\operatorname{trn} Q$ in $\mathrm{F}$ genomes and between $\operatorname{trn} H$ and $\operatorname{trn} Q$ in $\mathrm{M}$ genomes has been identified as a potential heavy strand origin of replication $(\mathrm{OH})$ [78]. Otherwise, F and $M$ unionoid mitochondrial genomes appear to contain multiple and potentially bidirectional OL control regions [78].

\section{Levels of intra- and interspecies sequence divergences}

It should be stressed that the measured divergences between unionoid $\mathrm{F}$ and $\mathrm{M}$ genomes considerably surpass intra- or inter-species values reported in classical model systems used for the study of intergenomic coevolution $[9,79,80]$. From a nucleo-mitochondrial evolutionary perspective, the question of how male freshwater mussels can tolerate heteroplasmy characterized by such variability remains to be solved.

Among species with DUI, freshwater mussels exhibit the greatest nucleotide and amino acid divergences between their gender-associated mtDNAs. For example, 
the average uncorrected nucleotide divergence observed between the $\mathrm{F}$ and $\mathrm{M}$ concatenated sequences of the 12 mitochondrial protein-coding genes of the marine mussel Mytilus edulis is about 23\% [31]. The smaller level of divergence observed between the M and F mtDNAs in Mytilus is likely associated with periodic "role-reversal" or "masculinization" events, which are characterized by an invasion of the male route of inheritance by an F-like genome that becomes transmitted through sperm as a standard M genome $[14,27,81,82]$. Specifically, the Flike, "recently-masculinized" M genome is only significantly different from a standard Mytilus F genome in that it possesses a so-called "standard M genome control region" and, as it's name implies, it is paternally transmitted (see [31] and [83] for details). Therefore, such masculinization events reset to zero the level of mitochondrial gene sequence divergence between the $M$ and $\mathrm{F}$ genomes. Complete absence of masculinization events, for over 200 million years, can explain the considerably greater divergences between unionoid $\mathrm{M}$ and $\mathrm{F}$ mtDNAs $[22,25,42]$. It has been proposed that the unionoid M-specific extension of the cytochrome $c$ oxidase subunit II gene represents such specialization of the unionoid $M$ genome that recombination (i.e. the addition of an $\mathrm{M}$ type genome's control region to an $\mathrm{F}$ genome) leading to role reversals are no longer possible in this taxon [83].

According to our results, 50\% amino acid divergence between unionoid $\mathrm{F}$ and $\mathrm{M}$ genomes can be tolerated by a species' nuclear environment without any major disruption of cytonuclear co-adaptation or impairment of mitochondrial function. This level of divergence could hardly be explained only by relaxation of selective pressure induced by a loss of metabolic function of $\mathrm{M}$ mtDNA since two recent studies have clearly shown the importance of $M$ mtDNA gene products on sperm performance in Mytilus edulis [84,85]. Further characterization of the conserved versus radical amino acid changes in evolutionarily conserved or non-conserved positions of mitochondrial proteins will help to delineate the levels/types of divergence in mtDNA encoded peptides that can be tolerated by a species' nuclear genome.

\section{Conclusions}

The basal position of the Unionoida within the autolamellibranch bivalves (Figure 1) and the hypothesized single origin of DUI (Figure 2B; [23,26-28]) suggest that (1) DUI arose in the ancestral autolamellibranch bivalve lineage and was subsequently lost in multiple descendant lineages and (2) the DUI characteristics observed in unionoid bivalves could more closely resemble the DUI ancestral condition. We described the general features of eight $\mathrm{mt}$ genomes from unionoid bivalve species with the doubly uniparental mode of mitochondrial inheritance and highlighted several unusual characteristics of the $\mathrm{M}$ genomes, compared to their female-transmitted counterparts, e.g., the presence of Mcox2e and a novel localization of $\operatorname{trnH}$. Based on the concatenated nucleotide sequences of 12 mitochondrial protein-coding genes, we determined an uncorrected amino acid pdistance between the $\mathrm{M}$ and $\mathrm{F}$ genomes of $\sim 50 \%$. From a nucleo-mitochondrial functional perspective, the question of how male freshwater mussels can tolerate heteroplasmy characterized by such variability remains to be solved as does the function(s) of DUI. Finally, the presence of the Mcox2e is one important feature that distinguishes markedly, but not solely, the unionoid $\mathrm{M}$ from the $\mathrm{F}$ genomes, but also the unionoid $\mathrm{M}$ from all other DUI-possessing bivalves as well as all other metazoan mtDNAs. This suggests that it could have been a facilitator of the transition from SMI to DUI in the ancestral autolamellibranch (assuming a single origin of DUI) or ancestral unionoid (assuming multiple origins of DUI) lineage. If the former hypothesis is corroborated, Mcox $2 e$ was subsequently lost from the $\mathrm{M}$ genome in the ancestor of the Pteriomorphia+Veneroida. Irrespective of a single vs. multiple origins of DUI, the ancestral character state reconstructions in Figure 4 imply that significant $\mathrm{mt}$ genomic reorganization occurred in the Bivalvia subsequent to the divergence of the unionoid lineage. Studying additional complete bivalve $\mathrm{mt}$ genomes will give us the best hope of unraveling the origin(s) and function(s) of DUI as well as the origins and consequences of the unique $\mathrm{mt}$ genomic variation in the Bivalvia.

\section{DNA extraction, PCR amplification and sequencing}

Mitochondrial DNA was extracted from one male and one female Venustaconcha ellipsiformis from Gladwin County, Michigan (USA), one male and one female Pyganodon grandis from the northern Radisson region of Québec (Canada) (48 $\left.18^{\prime} 24^{\prime \prime} \mathrm{N}, 68^{\circ} 29^{\prime} 34^{\prime \prime} \mathrm{W}\right)$ and one male and one female Quadrula quadrula from the White River, Indiana (USA). Microscopic examination of gonadal tissues was performed to determine mussel gender based on the presence of eggs or sperm/sperm morulae. Total genomic DNA extractions were performed on the tissues (gonadal tissue for the male and the female $P$. grandis and gonadal tissue for the males and mantle tissue for the females $V$. ellipsiformis and $Q$. quadrula) using a QIAGEN DNA Extraction Kit (QIAGEN Inc., Mississauga, Canada) following the manufacturer's protocol. Subsequently, each mitochondrial genome was amplified by long-PCR from the genomic DNA in two large overlapping regions using the F-specific primer FCOIIhFor (5'-GCCTTATG GGGTTGAT AGGCGAGTTCTTGTGAGG-3') with the 
amblemine-specific primer Ambl16SFor (5'-CTGGG TTTGCGACCTCGATGTTGGCTTAGGGAAA-3'), and the F-specific primer FCOI195R (5'-GCATAACAATTTC ACACAGGCCAATCATYATWGGYATNACCA-3') with the amblemine-specific Ambl16SRev (5'-TTTCCCTAAGCCAACATCGAGGTCGCAAACCC AG-3') for the F genomes of $V$. ellipsiformis and $Q$. quadrula, and the M-specific primer MCOIIh63F (5'CACGACGTTGTAAAACGACTTTATRCCTRTKTGT GTRGARGCTGT-3') with Ambl16SFor, and the M-specific MCOI19R (5'-GGATAACAATTTCACGGGTCC CAATATCYTTATGRTTAGT-3') with Ambl16SRev for the $M$ genomes of $V$. ellipsiformis and Q. quadrula. Both the $\mathrm{F}$ and $\mathrm{M}$ genomes of these species resulted in two fragments of $\sim 11 \mathrm{~kb}$ and $\sim 5.5 \mathrm{~kb}$, respectively. The F genome of $P$. grandis was also amplified in two large overlapping regions using the F-specific primer 5'FCOIPygR (5'-TGCCARTAACAARTAYAAAGTA-3') with ND1R (5-GCTATTAGTAGGTCGTATCG-3; [39,86]) and the F-specific primer UNIOND3 (5'-AGHSCKTTT GARTGYGGKTTTGA-3') with ND1F (5-TGGCA GAAAAGTGCATCAGATTTAAGC-3; $[39,87])$. We obtained two fragments of $\sim 11 \mathrm{~kb}$ and $\sim 7 \mathrm{~kb}$, respectively. The $\mathrm{M}$ genome of $P$. grandis was amplified with PygMcox2eF (5'-TTGAAGCAGTTAGAGTTG AGGT-3') in combination with 16Sar-L2 (5'-CGCC TGTTTAY CAAAAACAT-3'; modified from [88]) and PygMcox2eR (5'-TAYAATCTTYCAATRTCYTTATGA TT-3') combined with 16Sbr-H2 (5'-CCGGTCTGA ACTCAGATCRYGT-3'; modified from [88]). PygMcox2eF and PygMcox2eR were specifically designed to amplify the $\mathrm{M}$ genome. The resulting fragments were about $\sim 12 \mathrm{~kb}$ and $\sim 5.5 \mathrm{~kb}$.

Long-PCR amplifications were performed in $50 \mu \mathrm{l}$ reaction volumes using the QIAGEN LongRange PCR Kit in similar conditions to the manufacturers' suggestions: $1 \times$ LongRange PCR Buffer with $2.5 \mathrm{mM}$ of $\mathrm{Mg} 2+$, $500 \mu \mathrm{M}$ of each dNTP, $0.4 \mu \mathrm{M}$ each primer, $2 \mathrm{U}$ of LongRange PCR Enzyme Mix and 25 ng of template DNA. For the $\mathrm{M}$ and the $\mathrm{F}$ genomes of $V$. ellipsiformis and Q. quadrula, reactions were cycled at $85^{\circ} \mathrm{C}$ for $60 \mathrm{~s}$, $93^{\circ} \mathrm{C}$ for $60 \mathrm{~s}$, and 37 cycles of $93^{\circ} \mathrm{C}$ for $15 \mathrm{~s}, 53^{\circ} \mathrm{C}$ for $30 \mathrm{~s}$ and $68^{\circ} \mathrm{C}$ for $6 \mathrm{~min}$ for the short fragment or $11 \mathrm{~min}$ for the longest one. Thermal cycling conditions for the $\mathrm{M}$ and $\mathrm{F}$ genomes of $P$. grandis were as follows: $93^{\circ} \mathrm{C}$ for $3 \mathrm{~min}$, followed by 35 cycles of $93^{\circ} \mathrm{C}$ for $15 \mathrm{~s}$, $46-54^{\circ} \mathrm{C}$ for $30 \mathrm{~s}$ and $68^{\circ} \mathrm{C}$ for $7-12 \mathrm{~min}$ and a final extension at $72^{\circ} \mathrm{C}$ for $10 \mathrm{~min}$. Each amplicon appeared as one abundant band of the appropriate size on an agarose gel. The resulting PCR products were gel purified using QIAGEN QIAquick Gel Extraction Kit. Following DNA quantification for each amplicon, the two amplicons ( $\sim 5 \mathrm{~g}$ from each) for each genome were pooled and then processed for direct sequencing in a single reaction by the 454 Life Sciences Massively Parallel Pyrosequencing Platform (whole genome sequencing protocol) of the McGill University and Genome Quebec Innovation Center.

For the $\mathrm{M}$ and the $\mathrm{F}$ genomes of $V$. ellipsiformis, amplifications were pooled and a total of 10,413 reads were produced to provide at least $45 \times$ coverage of the complete mitochondrial genomes. The sequences were then assembled into a single contig of 15,975 base pairs (bp) for the F genome and 17,174 bp for the M genome. For the $\mathrm{M}$ and the $\mathrm{F}$ genomes of Q. quadrula, amplifications were pooled and a total of 11,978 reads were produced to provide at least $66 \times$ coverage of the complete mitochondrial genomes. The sequences were assembled into a single contig of $16,033 \mathrm{bp}$ for the $\mathrm{F}$ genome and 16,970 bp for the $\mathrm{M}$ genome. For the $P$. grandis $\mathrm{F}$ genome, draft assemblies were based on 14,794 total reads. The initial assembly of the 454 pyrosequencing data into two predominant contigs $(\sim 6.7 \mathrm{~kb})$ and a small one (834 bp) was provided by 454 Life Sciences (Branford, CT, USA), and corresponded to a mitochondrial genome coverage of $115 x$ and $437 \times$ respectively. The final assembly in one large contig of 15,848 bp was performed using SeqMan (DNAStar Inc., Madison, WI, USA). The complete $M$ genome of $P$. grandis was generated from assembly of 7,652 successful sequence reads into a single contig of $17,071 \mathrm{bp}$ which corresponded to an overall mitochondrial genome coverage of $>100 x$.

The complete sequences of the $\mathrm{F}$ and $\mathrm{M}$ mitochondrial genomes for Venustaconcha ellipsiformis, Pyganodon grandis and Quadrula quadrula can be accessed under the GenBank accession numbers FJ809753, FJ809752, FJ809754, FJ809755, FJ809750, and FJ809751, respectively.

\section{Gene annotation and analysis}

The complete $\mathrm{F}$ and $\mathrm{M}$ mitochondrial genomes for each species were initially analyzed with the NCBI Open Reading Frame Finder using the invertebrate mitochondrial code. Protein-coding and ribosomal RNA genes were annotated using DOGMA [88] and then aligned with the mtDNA genes annotated in GenBank using ClustalW [89]. The 5' and 3' ends of both rrnL and rrnS genes were assumed to be adjacent to the ends of bordering tRNA genes. Mitochondrial tRNA genes were identified and confirmed using a combination of programs: tRNAscan-SE 1.21 [90] with a COVE cutoff score of 0.1, DOGMA [89] and ARWEN [91]. Mitochondrial gene order comparisons were facilitated by the use of the OGRe web site at http://drake.physics. mcmaster.ca/ogre/index.shtml[59].

Basic sequence statistics and evolutionary distances among genes were performed using MEGA version 4.0 [92] and DnaSP version 4.0 [93]. To estimate 
evolutionary distance between pairwise comparisons, the following parameters were used: uncorrected nucleotide divergence ( $\mathrm{Pi}=$ uncorrected nucleotide diversity), nucleotide divergence using the Jukes-Cantor (JC), Kimura two-parameter (K2P), and Tamura and Nei $(\operatorname{TrN})$ models of nucleotide substitution. Estimated parameters also included total amino acid differences $(\mathrm{Na})$, uncorrected amino acid distances ( $\mathrm{p}(\mathrm{aa})$ ), poisson-corrected amino acid distances $(D)$, number of synonymous substitutions per synonymous site $\left(\mathrm{K}_{\mathrm{s}}\right)$ and number of nonsynonymous substitution per nonsynonymous site $\left(K_{a}\right)$ [94]. The Jukes-Cantor correction for multiple substitutions was applied. Strand asymmetry was measured using the formulas AT-skew $=(\mathrm{A}-\mathrm{T}) /(\mathrm{A}+\mathrm{T})$ and CGskew $=(C-G) /(C+G)[51,95]$ and calculated with MEGA 4.0 [92] at fourfold redundant sites for each mitochondrial protein-coding gene.

Phylogenetic trees for the Bivalvia, using Bayesian inference (BI), maximum likelihood (ML) and maximum parsimony (MP), were constructed using concatenated nucleotide and amino acid sequences from 12 proteincoding genes (we excluded atp 8 due to alignment issues and its apparent absence in multiple bivalve species). We used both Clustal W [96] and Dialign version 2.2.1 [97] for the alignments, with subsequent manual adjustments, and the amino acid alignment was used as a template to align the corresponding codons. Amino acids from 29 complete bivalve mitochondrial genomes and those from five outgroup species (gastropod Aplysia californica [NC_005827], cephalopod Octopus vulgaris [NC_006353], scaphopod Graptacme eborea [NC_006162], polyplacophoran, Katharina tunicata [NC_001636], polychaete Platynereis dumerii [NC_000931]) were aligned using Clustal W in MEGA 4.0 and manually reviewed (Table 1). Regions of ambiguous alignment were excluded prior to the phylogenetic analyses. The analyzed matrices had either 7,704 nucleotide positions or 2,568 amino acid positions and these files are available from the authors.

The codon- and amino acid-based BI analyses were conducted with Mr. Bayes (v. 3.1.2; $[98,99])$. The codonbased analysis invoked the M3 model [100] with two simultaneous runs of 5 million generations each (a total of 50,000 saved trees/run). The amino acid-based BI analysis invoked the variable rate "glorified GTR model" (see the MrBayes manual;[101]) with two simultaneous runs of 2.9 million generations each (a total of 29,000 saved trees/run). Both sets of BI analyses reached convergence (average standard deviation of the split frequencies was $<0.01$ ) and the burnin for each set was determined by reference to the log probability of observing the data $\times$ generation plot (codon-based BI run burnin $=4$ million generations $[=$ the last 10,000 trees/ run saved contributed to the majority-rule tree], amino acid-based BI run burnin = 1.9 million generations $[=$ the last 10,000 trees/run saved contributed to the majority-rule tree]).

Codon and amino acid-based ML analyses were conducted with Garli (v. 0.96;[102]). The M3 model was used in the codon-based ML analysis which was set to use the observed nucleotide frequencies at each codon position separately. A non-parametric bootstrap [103] analysis was performed, using 300 replicates, to assess nodal support for the codon analysis-based trees. The program ProtTest http://darwin.uvigo.es/software/prottest.html was used to evaluate the best amino acid model for our data from those models available in Garli. Both the Akaike information criterion and Bayesian information criterion selected the WAG+F model [104] as the best available model which was therefore used in the ML amino acid analysis. A non-parametric bootstrap was performed, using 600 replicates, to assess nodal support for the a.a. analysis-based trees.

Maximum parsimony analyses were conducted with PAUP* [105]. The nucleotide-based MP analysis utilized equally weighted transversion parsimony ( $=$ only purines vs. pyrimidines were coded) and 1000 random addition runs for estimating the most parsimonious tree. A nonparametric bootstrap transversion parsimony analysis was run (with 1000 replicates) using 10 random addition runs per replicate. The amino acid-based MP analysis was carried out with equal weighting and 1000 random addition runs were used to estimate the most parsimonious tree. Lastly, an equally weighted parsimony, nonparametric, bootstrap analysis was run on the a.a. matrix (with 1000 replicates) using 10 random addition runs per replicate.

The estimation of ancestral mitogenomic character states and the presence/absence of DUI, based on the majority-rule codon-based BI tree, was carried out using the ML algorithm in Mesquite (v.2.6; [106]). An estimation of ancestral character states for the presence/ absence of DUI, using the best codon-based BI tree and Dollo parsimony, was done with MacClade (v.4.07; [107]). The asymmetry likelihood ratio test was used to determine whether the AsymmMK model was significantly better than the MK1 model (see the Mesquite manual). The MK1 model was used in all likelihood reconstructions because in all cases, the AsymmMK model was not a significantly better model, therefore we used the simpler model (the MK1 model has one less parameter). The use of a likelihood ratio test to calculate $P$-values for ancestral states is not possible because hypotheses regarding the likelihoods of each possible state at a given node are non-nested. Therefore, to make decisions regarding the significance of ancestral character states Pagel ([108] following [109]), recommended that ancestral character state estimates with a 
log likelihood two or more units lower than the best state estimate (decision threshold $[\mathrm{T}]$ set to $\mathrm{T}=2$ ) be rejected. Generally viewed as a conservative cutoff, this threshold has been used by numerous recent authors (e. g., [110-112]). For the data presented herein, this protocol ensures that all of the character states judged to be significant have proportional likelihoods at least 10 times greater than that of any other state.

Additional file 1: Supplemental figures. Figure S1. Inferred secondary structures of the 22 mitochondrial tRNAs from $\mathrm{F}$ Venustaconcha ellipsiformis, shown in the order they occur in the genome, beginning with $\mathrm{trnH}$. Amino acid identities are given above each sequence. Figure S2. Inferred secondary structures of the 22 mitochondrial tRNAs from M Venustaconcha ellipsiformis, shown in the order they occur in the genome, beginning with trnA. Amino acid identities are given above each sequence. Figure S3. Inferred secondary structures of the 22 mitochondrial tRNAs from F Pyganodon grandis, shown in the order they occur in the genome, beginning with $t r n \mathrm{H}$. Amino acid identities are given above each sequence. Figure S4. Inferred secondary structures of the 22 mitochondrial tRNAs from M Pyganodon grandis, shown in the order they occur in the genome, beginning with $\operatorname{trn} A$. Amino acid identities are given above each sequence. Figure S5. Inferred secondary structures of the 22 mitochondrial tRNAs from $\mathrm{F}$ Inversidens japanensis, shown in the order they occur in the genome, beginning with $\operatorname{trnH}$. Amino acid identities are given above each sequence. Figure $\mathbf{5 6 .}$ Inferred secondary structures of the 22 mitochondrial tRNAs from M Inversidens japanensis, shown in the order they occur in the genome, beginning with trnA. Amino acid identities are given above each sequence. Figure S7. Inferred secondary structures of the 22 mitochondrial tRNAs from F Quadrula quadrula, shown in the order they occur in the genome, beginning with $\mathrm{trnH}$. Amino acid identities are given above each sequence. Figure S8. Inferred secondary structures of the 22 mitochondrial tRNAs from M Quadrula quadrula, shown in the order they occur in the genome, beginning with trnA. Amino acid identities are given above each sequence.

Click here for file

[http://www.biomedcentral.com/content/supplementary/1471-2148-1050-S1.PDF ]

Additional file 2: Table S1. Codon usage in the female- and maletransmitted mitochondrial genomes of Venustaconcha ellipsiformis, Pyganodon grandis, Inversidens japanensis and Quadrula quadrula. Table of the codon usage in the female- and male-transmitted mitochondrial genomes of Venustaconcha ellipsiformis, Pyganodon grandis, Inversidens japanensis and Quadrula quadrula.

Click here for file

[http://www.biomedcentral.com/content/supplementary/1471-2148-1050-S2.DOC]

\section{Acknowledgements}

This work was supported by research grants from the National Science Foundation (NSF DEB-0237175, to WR Hoeh), the National Sciences and Engineering Research Council (NSERC, to PU Blier and DT Stewart) and by AE Bogan's research funds. $H$. Doucet Beaupré and S Breton were financially supported by a NSERC scholarship and a NSERC fellowship, respectively. EG Chapman is supported by the Kentucky Agricultural Experiment Station State Project KY008043.

\section{Author details}

'Département de Biologie, Université du Québec à Rimouski, 300 Allée des Ursulines, Rimouski, Québec, G5L 3A1, Canada. 2Department of Biological Sciences, Kent State University, Kent, Ohio 44242, USA. ${ }^{3}$ Department of Entomology, University of Kentucky, Lexington, Kentucky, 40546-0091 USA. ${ }^{4}$ North Carolina State Museum of Natural Sciences, Research Laboratory, MSC
1626, Raleigh, North Carolina, 27699-1626 USA. ${ }^{5}$ Department of Biology, Acadia University, 33 Westwood Ave, Wolfville, NS, B4P 2R6, Canada .

\section{Authors' contributions}

HDB and SB conceived the study, sequenced and annotated the new mitochondrial genomes. HDB aligned the sequence, analyzed the data, and drafted the manuscript. EGC conducted the computational phylogenetic analysis. PUB participated in coordination of the study and also helped to improve the manuscript. AEB provided tissue samples for DNA extraction and material support for the sequencing. DTS helped in interpreting the data and revising the manuscript. WRH also conceived the study and participated in its design, in data analysis and in drafting the manuscript. All authors read and approved the final manuscript.

Received: 28 September 2009

Accepted: 18 February 2010 Published: 18 February 2010

\section{References}

1. Boore JL: Animal mitochondrial genomes. Nucl Acids Res 1999, 27:1767-1780

2. Attardi G: Animal mitochondrial DNA: an extreme example of genetic economy. Int Rev Cytol 1985, 93:93-145.

3. Gissi C, lannelli F, Pesole G: Evolution of the mitochondrial genome of Metazoa as exemplified by comparison of congeneric species. Heredity 2008, 101:301-320.

4. Xu JP: The inheritance of organelle genes and genomes: patterns and mechanisms. Genome 2005, 48:951-958.

5. Elson $\mathrm{JL}$, Lightowlers RN: Mitochondrial DNA clonality in the dock: can surveillance swing the case?. Trends Genet 2006, 22:603-607.

6. Birky CW: The inheritance of genes in mitochondria and chloroplasts: Laws, mechanisms, and models. Annu Rev Genet 2001, 35:125-148.

7. Rand DM: The units of selection on mitochondrial DNA. Annu Rev Ecol Syst 2001, 32:415-448.

8. Shoubridge EA, Wai T: MEDICINE: Sidestepping Mutational Meltdown. Science 2008, 319:914-915.

9. Breton S, Doucet-Beaupré H, Stewart DT, Hoeh WR, Blier PU: The unusual system of doubly uniparental inheritance of mtDNA: isn't one enough? Trends Genet 2007, 23:465-474.

10. Passamonti M, Ghiselli F: Doubly uniparental inheritance: two mitochondrial genomes, one precious model for organelle DNA inheritance and evolution. DNA Cell Biol 2009, 28:79-89.

11. Sutherland $B$, Stewart $D$, Kenchington ER, Zouros E: The fate of paternal mitochondrial DNA in developing female mussels, Mytilus edulis : Implications for the mechanism of doubly uniparental inheritance of mitochondrial DNA. Genetics 1998, 148:341-347.

12. Obata M, Sano N, Kawamura K, Komaru A: Inheritance of two M type mitochondrial DNA from sperm and unfertilized eggs to offspring in Mytilus galloprovincialis. Dev Growth Differ 2007, 49:335-344.

13. Garrido-Ramos MA, Stewart DT, Sutherland BW, Zouros E: The distribution of male-transmitted and female-transmitted mitochondrial DNA types in somatic tissues of blue mussels: Implications for the operation of doubly uniparental inheritance of mitochondrial DNA. Genome 1998, 41:818-824.

14. Venetis C, Theologidis I, Zouros E, Rodakis GC: No evidence for presence of maternal mitochondrial DNA in the sperm of Mytilus galloprovincialis males. Proc R Soc London Ser B 2006, 273:2483-2489.

15. Obata M, Kamiya C, Kawamura K, Komaru A: Sperm mitochondrial DNA transmission to both male and female offspring in the blue mussel Mytilus galloprovincialis. Dev Growth Differ 2006, 48:253-261.

16. Chakrabarti R, Walker JM, Chapman EG, Shepardson SP, Trdan RJ, Curole JP, Watters, Stewart DT, Vijayaraghavan S, Hoeh WR: Reproductive function for a C-terminus extended, male-transmitted cytochrome c oxidase subunit II protein expressed in both spermatozoa and eggs. FEBS Lett 2007, 581:5213-5219.

17. Rawson PD, Hilbish TJ: Evolutionary relationships among the male and female mitochondrial-DNA lineages in the Mytilus edulis species complex. Mol Biol Evol 1995, 12:893-901.

18. Stewart DT, Saavedra C, Stanwood RR, Ball AO, Zouros E: Male and female mitochondrial DNA lineages in the blue mussel Mytilus. Mol Biol Evol 1995, 12:735-747.

19. Stewart DT, Kenchington ER, Singh RK, Zouros E: Degree of selective constraint as an explanation of the different rates of evolution of 
gender-specific mitochondrial DNA lineages in the mussel Mytilus. Genetics 1996, 143:1349-1357.

20. Hoeh WR, Stewart DT, Sutherland BW, Zouros E: Multiple origins of gender-associated mitochondrial DNA lineages in bivalves (Mollusca: Bivalvia). Evolution 1996, 50:2276-2286.

21. Passamonti M, Scali V: Gender-associated mitochondrial DNA heteroplasmy in the venerid clam Tapes philippinarum (Mollusca Bivalvia). Curr Genet 2001, 39:117-124.

22. Curole JP, Kocher TD: Ancient sex-specific extension of the cytochrome $c$ oxidase II gene in bivalves and the fidelity of doubly-uniparental inheritance. Mol Biol Evol 2002, 19:1323-1328.

23. Hoeh WR, Stewart DT, Guttman SI: High fidelity of mitochondrial genome transmission under the doubly uniparental mode of inheritance in freshwater mussels (Bivalvia: Unionoidea). Evolution 2002, 56:2252-2261.

24. Passamonti M, Boore JL, Scali V: Molecular evolution and recombination in gender-associated mitochondrial DNAs of the manila clam Tapes philippinarum. Genetics 2003, 164:603-611.

25. Walker JM, Curole JP, Wade DE, Chapman EG, Bogan AE, Watters GT, Hoeh WR: Taxonomic distribution and phylogenetic utility of genderassociated mitochondrial genomes in the Unionoida (Bivalvia). Malacologia 2006, 48:265-282.

26. Theologidis I, Fodelianakis S, Gaspar MB, Zouros E: Doubly uniparental inheritance (DUI) of mitochondrial dna in Donax trunculus (Bivalvia: Donacidae) and the problem of its sporadic detection in Bivalvia. Evolution 2008, 62:959-970

27. Zouros E: The exceptional mitochondrial DNA system of the mussel family Mytilidae. Genes Genet Syst 2000, 75:313-318.

28. Obata M, Shimizu M, Sano N, Komaru A: Maternal inheritance of mitochondrial DNA (mtDNA) in the Pacific oyster (Crassostrea gigas): a preliminary study using mtDNA sequence analysis with evidence of random distribution of MitoTracker-stained sperm mitochondria in fertilized eggs. Zool Sci 2008, 25:248-254.

29. Hoeh WR, Stewart DT, Sutherland BW, Zouros E: Cytochrome c oxidase sequence comparisons suggest an unusually high rate of mitochondrial DNA evolution in Mytilus (Mollusca: Bivalvia). Mol Biol Evol 1996, 13:418-421.

30. Liu HP, Mitton JB, Wu SK: Paternal mitochondrial DNA differentiation far exceeds maternal mitochondrial DNA and allozyme differentiation in the freshwater mussel, Anodonta grandis grandis. Evolution 1996, 50:952-957.

31. Breton S, Burger G, Stewart DT, Blier PU: Comparative analysis of genderassociated complete mitochondrial genomes in marine mussels (Mytilus spp.). Genetics 2006, 172:1107-1119.

32. Hoffman RJ, Boore JL, Brown WM: A novel mitochondrial genome organization for the blue mussel, Mytilus edulis. Genetics 1992 131:397-412.

33. Boore $J$, Medina M, Rosenberg LA: Complete sequences of the highly rearranged molluscan mitochondrial genomes of the scaphopod Graptacme eborea and the bivalve Mytilus edulis. Mol Biol Evol 2004, 21:1492-1503.

34. Mizi A, Zouros E, Moschonas N, Rodakis GC: The complete maternal and paternal mitochondrial genomes of the mediterranean mussel Mytilus galloprovincialis : Implications for the doubly uniparental inheritance mode of mtDNA. Mol Biol Evol 2005, 22:952-967.

35. Venetis C, Theologidis I, Zouros E, Rodakis GC: A mitochondrial genome with a reversed transmission route in the Mediterranean mussel Mytilus galloprovincialis. Gene 2007, 406:79-90.

36. Zbawicka M, Burzynski A, Wenne R: Complete sequences of mitochondrial genomes from the Baltic mussel Mytilus trossulus. Gene 2007, 406:191-198.

37. Serb JM, Lydeard C: Complete mtDNA sequence of the north American freshwater mussel, Lampsilis ornata (Unionidae): An examination of the evolution and phylogenetic utility of mitochondrial genome organization in bivalvia (Mollusca). Mol Biol Evol 2003, 20:1854-1866.

38. Valles $Y$, Boore JL: Lophotrochozoan mitochondrial genomes. Integr Comp Biol 2006, 46:544-557.

39. Smith DR, Snyder M: Complete mitochondrial DNA sequence of the scallop Placopecten magellanicus : Evidence of transposition leading to an uncharacteristically large mitochondrial genome. J Mol Evol 2007, 65:380-391.

40. Milbury CA, Gaffney PM: Complete mitochondrial DNA sequence of the eastern oyster Crassostrea virginica. Mar Biotechnol 2005, 7:697-712.
41. Dreyer $\mathrm{H}$, Steiner $\mathrm{G}$ : The complete sequence and gene organization of the mitochondrial genomes of the heterodont bivalves Acanthocardia tuberculata and Hiatella arctica and the first record for a putative Atpase subunit 8 gene in marine bivalves. Front Zool 2006, 3:13.

42. Curole JP, Kocher TD: Evolution of a unique mitotype-specific proteincoding extension of the cytochrome $\mathrm{c}$ oxidase II gene in freshwater mussels (Bivalvia: Unionoida). J Mol Evol 2005, 61:381-389.

43. Chapman EG, Piontkivska H, Walker JM, Stewart DT, Curole JP, Hoeh WR: Extreme primary and secondary protein structure variability in the chimeric male-transmitted cytochrome c oxidase subunit II protein in freshwater mussels: Evidence for an elevated amino acid substitution rate in the face of domain-specific purifying selection. BMC Evol Biol 2008, 8:165.

44. Healy JM: Spermiogenesis and spermatozoa in the relict bivalve genus Neotrigonia : relevance to trigonioid relationships, particularly with Unionoidea. Mar Biol 1989, 103:75-85.

45. Hoeh WR, Black MB, Gustafson R, Bogan AE, Lutz RA, Vrijenhoek RC: Testing alternative hypotheses of Neotrigonia (Bivalvia: Trigonioida) phylogenetic relationships using cytochrome $\mathrm{C}$ oxidase subunit I DNA sequences. Malacologia 1998, 40:267-278.

46. Graf $\mathrm{DL}, \mathrm{O}^{\prime}$ Foighil $\mathrm{D}$ : The evolution of brooding characters among the freshwater pearly mussels (Bivalvia: Unionoidea) of North America. $J$ Mollus Stud 2000, 66:157-170.

47. Giribet $\mathrm{G}$, Wheeler W: On bivalve phylogeny: a high-level analysis of the Bivalvia (Mollusca) based on combined morphology and DNA sequence data. Invert Biol 2002, 121:271-324.

48. Giribet G, Distel DL: Bivalve phylogeny and molecular data. Molecular Systematics and Phylogeography of Mollusks Washington DC; Smithsonian BooksLydeard C, Lindberg DR 2003, 45-90.

49. Graf DL, Cummings KS: Palaeoheterodont diversity (Mollusca: Trigonioida + Unionoida): what we know and what we wish we knew about freshwater mussel evolution. Zool J Linn Soc 2006, 148:343-394.

50. Grande C, Templado J, Zardoya R: Evolution of gastropod mitochondrial genome arrangements. BMC Evol Biol 2008, 8:61.

51. Perna NT, Kocher TD: Patterns of nucleotide composition at fourfold degenerate sites of animal mitochondrial genomes. J Mol Evol 1995, 41:353-358.

52. Francino MP, Ochman H: Strand asymmetries in DNA evolution. Trends Genet 1997, 13:240-245.

53. Giribet G: Bivalvia. Phylogeny and Evolution of the Mollusca Berkeley, CA: University of California PressPonder W, Lindberg DR 2008, 105-142.

54. Krebs RA: Combining paternally and maternally inherited mitochondrial DNA for analysis of population structure in mussels. Mol Ecol 2004, 13:1701-1705.

55. Le Quesne WJ: The uniquely evolved character concept and its cladistic application. Syst Zool 1974, 23:513-517.

56. Farris JS: Phylogenetic analysis under Dollo's Law. Syst Zool 1977, 26:77-88.

57. Boore JL: The complete sequence of the mitochondrial genome of Nautilus macromphalus (Mollusca: Cephalopoda). BMC Genomics 2006, 7:182.

58. Knudsen B, Kohn AB, Nahir B, McFadden CS, Moroz LL: Complete DNA sequence of the mitochondrial genome of the sea-slug, Aplysia californica : Conservation of the gene order in Euthyneura. $\mathrm{Mol}$ Phylogenet Evol 2006, 38:459-469.

59. Jameson D, Gibson AP, Hudelot C, Higgs PG: OGRe: a relational database for comparative analysis of mitochondrial genomes. Nucl Acids Res 2003, 31:202-206.

60. Giribet G, Dunn CW, Edgecombe GD, Kristensen RM, Hejnol A, Pleijel F, Rouse GW, Sorensen MV, Worsaae K: A new dimension in combining data? The use of morphology and phylogenomic data in metazoan systematics. J Morphol 2008, 269:1462-1462.

61. Boore JL, Lavrov DV, Brown WM: Gene translocation links insects and crustaceans. Nature 2006, 392:667-668.

62. Dowton M, Austin AD: Evolutionary dynamics of a mitochondrial rearrangement "hot spot" in the Hymenoptera. Mol Biol Evol 1999, 16:298-309.

63. Mueller RL, Boore JL: Molecular mechanisms of extensive mitochondrial gene rearrangement in plethodontid salamanders. Mol Biol Evol 2005, 22:2104-2112

64. Cantatore P, Gadaleta MN, Roberti M, Saccone C, Wilson AC: Duplication and remoulding of tRNA genes during the evolutionary rearrangement of mitochondrial genomes. Nature 1987, 329:853-855. 
65. Chakrabarti R, Walker JM, Stewart DT, Trdan RJ, Vijayaraghavan S, Curole JP, Hoeh WR: Presence of a unique male-specific extension of C-terminus to the cytochrome c oxidase subunit II protein coded by the maletransmitted mitochondrial genome of Venustaconcha ellipsiformis (Bivalvia: Unionoidea). FEBS Lett 2006, 580:862-866.

66. Cao $L$, Kenchington $E$, Zouros $E$ : Differential segregation patterns of sperm mitochondria in embryos of the blue mussel (Mytilus edulis). Genetics 2004, 166:883-894.

67. Cogswell AT, Kenchington ELR, Zouros E: Segregation of sperm mitochondria in two- and four-cell embryos of the blue mussel Mytilus edulis : implications for the mechanism of doubly uniparental inheritance of mitochondrial DNA. Genome 2006, 49:799-807.

68. Devenish RJ, Prescott M, Roucou X, Nagley P: Insights into ATP synthase assembly and function through the molecular genetic manipulation of subunits of the yeast mitochondrial enzyme complex. BBA - Bioenergetics 2000, 1458:428-442.

69. Pesole G, Gissi C, De Chirico A, Saccone C: Nucleotide substitution rate of mammalian mitochondrial genomes. J Mol Evol 1999, 48:427-434.

70. Yu Z, Wei Z, Kong X, Shi W: Complete mitochondrial DNA sequence of oyster Crassostrea hongkongensis -a case of "Tandem duplicationrandom loss" for genome rearrangement in Crassostrea ?. BMC Genomics 2008, 9:477.

71. Okimoto R, Macfarlane JL, Clary DO, Wolstenholme DR: The mitochondrial genomes of two nematodes, Caenorhabditis elegans and Ascaris suum. Genetics 1992, 130:471-498.

72. Le TH, Blair D, Agatsuma T, Humair PF, Campbell NJ, Iwagami M, Littlewood DT, Peacock B, Johnston DA, Bartley J, Rollinson D, Herniou EA, Zarlenga DS, McManus DP: Phylogenies inferred from mitochondrial gene orders-A cautionary tale from the parasitic flatworms. Mol Biol Evol 2000, 17:1123-1125

73. Wolstenholme DR: Animal mitochondrial DNA: structure and evolution. Mitochondrial genomes. International Review of Cytology New York: Academic PressWolstenholme DR, Jeon KW 1992, 141:173-216.

74. Reyes A, Gissi C, Pesole G, Saccone C: Asymmetrical directional mutation pressure in the mitochondrial genome of mammals. Mol Biol Evol 1998, 15:957-966.

75. Fuller KM, Zouros E: Dispersed discrete length polymorphism of mitochondrial DNA in the scallop Placopecten magellanicus (Gmelin). Curr Genet 1993, 23:365-369.

76. Rigaa A, Monnerot M, Sellos D: Molecular cloning and complete nucleotide sequence of the repeated unit and flanking gene of the scallop Pecten maximus mitochondrial DNA: putative replication origin features. J Mol Evol 1995, 41:189-195.

77. Carapelli A, Comandi S, Convey P, Nardi F, Frati F: The complete mitochondrial genome of the Antarctic springtail Cryptopygus antarcticus (Hexapoda: Collembola). BMC Genomics 2008, 9:315-327.

78. Breton S, Beaupre HD, Stewart DT, Piontkivska H, Karmakar M, Bogan AE, Blier PU, Hoeh WR: Comparative mitochondrial genomics of freshwater mussels (Bivalvia: Unionoida) with doubly uniparental inheritance of mtDNA: gender-specific open reading frames and putative origins of replication. Genetics 2009, 183:1575-1589.

79. Blier PU, Dufresne F, Burton RS: Natural selection and the evolution of mtDNA-encoded peptides: evidence for intergenomic co-adaptation. Trends Genet 2001, 17:400-406.

80. Blier PU, Breton S, Desrosiers V, Lemieux H: Functional conservatism in mitochondrial evolution: Insight from hybridization of arctic and brook charrs. J Exp Zool B Mol Dev Evol 2006, 306B:425-432.

81. Hoeh WR, Stewart DT, Saavedra C, Sutherland BW, Zouros E: Phylogenetic evidence for role-reversals of gender-associated mitochondrial DNA in Mytilus (Bivalvia: Mytilidae). Mol Biol Evol 1997, 14:959-967.

82. Saavedra C, Reyero Ml, Zouros E: Male-dependent doubly uniparental inheritance of mitochondrial DNA and female-dependent sex-ratio in the mussel Mytilus galloprovincialis. Genetics 1997, 145:1073-1082.

83. Stewart DT, Breton S, Blier PU, Hoeh WR: Masculinization events and doubly uniparental inheritance of mitochondrial DNA: A model for understanding the evolutionary dynamics of gender-asssociated mtDNA in mussels. Evolutionary Biology from Concept to Application // Berlin: Springer-VerlagPontarotti $P$

84. Jha M, Côté J, Hoeh WR, Blier PU, Stewart DT: Sperm motility in Mytilus edulis in relation to mitochondrial DNA polymorphisms: implications for the evolution of doubly uniparental inheritance in bivalves. Evolution 2008, 62:99-106.

85. Breton S, Stewart DT, Blier PU: Role-reversal of gender-associated mitochondrial DNA affects mitochondrial function in Mytilus edulis (Bivalvia: Mytilidae). J Exp Zool B Mol Dev Evol 2009, 312B:108-117.

86. Buhay JE, Serb JM, Dean CR, Parham Q, Lydeard C: Conservation genetics of two endangered unionid bivalve species, Epioblasma florentina walkeri and E. Capsaeformis (Unionidae: Lampsilini). J Mollus Stud 2002, 68:385-391.

87. Palumbi SR: Nucleic Acids II: The Polymerase Chain Reaction. Molecular Systematics Sunderland: Sinauer AssociatesHillis DM, Moritz C, Mable BK 1996, 205-247.

88. Wyman SK, Jansen RK, Boore JL: Automatic annotation of organellar genomes with DOGMA. Bioinformatics 2004, 20:3252-3255.

89. Thompson JD, Higgins DJ, Gibson TJ: CLUSTAL W: improving the sensitivity of progressive multiple sequence alignment through sequence weighting, position-specific gap penalties and weight matrix choice. Nucl Acids Res 1994, 22:4673-4680.

90. Lowe TM, Eddy SR: tRNAscan-SE: a program for improved detection of transfer RNA genes in genomic sequence. Nucl Acids Res 1997, 25:955-964.

91. Laslett D, Canback B: ARWEN: a program to detect tRNA genes in metazoan mitochondrial nucleotide sequences. Bioinformatics 2008, 24:172-175.

92. Kumar S, Tamura K, Jakobsen IB, Nei M: MEGA2: molecular evolutionary genetics analysis software. Bioinformatics 2001, 17:1244-1245

93. Rozas J, Sanchez-DelBarrio JC, Messeguer X, Rozas R: DnaSP, DNA polymorphism analyses by the coalescent and other methods. Bioinformatics 2003, 19:2496-2497.

94. Nei M, Gojobori T: Simple methods for estimating the numbers of synonymous and nonsynonymous nucleotide substitutions. Mol Biol Evol 1986, 3:418-426.

95. Hassanin A, Leger N, Deutsch J: Evidence for multiple reversals of asymmetric mutational constraints during the evolution of the mitochondrial genome of Metazoa, and consequences for phylogenetic inferences. Syst Biol 2005, 54:277-298.

96. Larkin MA, Blackshields G, Brown NP, Chenna R, McGettigan PA, McWilliam H, Valentin F, Wallace IM, Wilm A, Lopez R, Thompson JD, Gibson TJ, Higgins DG: ClustalW and ClustalX version 2. Bioinformatics 2007, 23:2947-2948.

97. Subramanian AR, Kaufmann M, Morgenstern B: DIALIGN-TX: greedy and progressive approaches for segment-based multiple sequence alignment. Algorithms Mol Biol 2008, 3:6.

98. Huelsenbeck JP, Ronquist F: MRBAYES: Bayesian inference of phylogenetic trees. Bioinformatics 2001, 17:754-755.

99. Ronquist F, Huelsenbeck JP: MrBayes 3: Bayesian phylogenetic inference under mixed models. Bioinformatics 2003, 19:1572-1574.

100. Yang Z, Nielsen R, Goldman N, Pedersen AMK: Codon-substitution models for heterogeneous selection pressure at amino acid sites. Genetics 2000, 155:431-449.

101. Ronquist F, Huelsenbeck JP, Mark van der P: MrBayes 3.1 manual. 2005http://mrbayes.csit.fsu.edu/mb3.1_manual.pdf.

102. Zwickl DJ: Genetic algorithm approaches for the phylogenetic analysis of large biological sequence datasets under the maximum likelihood criterion. PhD thesis The University of Texas at Austin 2006.

103. Felsenstein J: Confidence limits on phylogenies: An approach using the bootstrap. Evolution 1985, 39:783-791.

104. Whelan S, Goldman N: A general empirical model of protein evolution derived from multiple protein families using a maximum likelihood approach. Mol Biol Evol 2001, 18:691-699.

105. Swofford DL: PAUP*. Phylogenetic Analysis Using Parsimony (*and Other Methods). Sunderland: Sinauer Associates 2002http://paup.csit.fsu.edu.

106. Maddison WP, Maddison DR: Mesquite: a modular system for evolutionary analysis. Version 2.6. 2008http://mesquiteproject.org.

107. Maddison DR, Maddison WP: MacClade 4: Analysis of Parsimony and Character Evolution Sunderland: Sinauer Associates, 4.06 2003.

108. Pagel M: The maximum likelihood approach to reconstructing ancestral character states of discrete characters on phylogenies. Syst Biol 1999, 48:612-622.

109. Edwards AWF: Likelihood Cambridge: Cambridge University Press 1972. 
110. Fernandez AA, Morris MR: Sexual selection and trichromatic color vision in primates: Statistical support for the preexisting-bias hypothesis. Am Nat 2007, 170:10-20.

111. Murphy NP, Carey D, Castro LR, Dowton M, Austin AD: Phylogeny of the platygastroid wasps (Hymenoptera) based on sequences from the $18 \mathrm{~S}$ rRNA, 28S rRNA and cytochrome oxidase I genes: implications for the evolution of the ovipositor system and host relationships. Biol J Linnean 2007, 91:653-669.

112. Koepfli KP, Deere KA, Slater GJ, Begg C, Begg K, Grassman L, Lucherini M, Veron G, Wayne RK: Multigene phylogeny of the Mustelidae: Resolving relationships, tempo and biogeographic history of a mammalian adaptive radiation. BMC Biol 2008, 6:10.

113. Conant GC, Wolfe KH: GenomeVx: simple web-based creation of editable circular chromosome maps. Bioinformatics 2008, 24:861-862.

doi:10.1186/1471-2148-10-50

Cite this article as: Doucet-Beaupré et al:: Mitochondrial phylogenomics of the Bivalvia (Mollusca): searching for the origin and mitogenomic correlates of doubly uniparental inheritance of mtDNA. BMC Evolutionary Biology 2010 10:50.

\section{Submit your next manuscript to BioMed Central} and take full advantage of:

- Convenient online submission

- Thorough peer review

- No space constraints or color figure charges

- Immediate publication on acceptance

- Inclusion in PubMed, CAS, Scopus and Google Scholar

- Research which is freely available for redistribution

Submit your manuscript at www.biomedcentral.com/submit
C Biomed Central 